\title{
Firm Productivity in Bangladesh Manufacturing Industries
}

\author{
Ana M. Fernandes* \\ The World Bank
}

\begin{abstract}
This paper studies the determinants of total factor productivity (TFP) for manufacturing firms in Bangladesh using data from a recent survey. TFP measures are obtained following Olley and Pakes (1996) and making use of firm-specific deflators for output and inputs. Controlling for industry, location, and year fixed effects, we find that: (i) firm size and TFP are negatively correlated; (ii) firm age and TFP exhibit an inverse-U shaped relationship; (iii) TFP improves with the quality of the firm's human capital; (iv) global integration improves TFP; (v) firms with R\&D activities and quality certifications have higher TFP, while more advanced technologies improve TFP only in the presence of significant absorptive capacity; (vi) power supply problems cost firms heavily in terms of TFP losses; and (vii) the presence of crime dampens TFP.
\end{abstract}

JEL Classification Numbers: D24, F23, L25 O33.

Keywords: Total Factor Productivity, Simultaneity and Production Functions, Skilled Labor, Openness, Business Environment, Bangladesh.

World Bank Policy Research Working Paper 3988, August 2006

The Policy Research Working Paper Series disseminates the findings of work in progress to encourage the exchange of ideas about development issues. An objective of the series is to get the findings out quickly, even if the presentations are less than fully polished. The papers carry the names of the authors and should be cited accordingly. The findings, interpretations, and conclusions expressed in this paper are entirely those of the authors. They do not necessarily represent the view of the World Bank, its Executive Directors, or the countries they represent. Policy Research Working Papers are available online at http://econ.worldbank.org.

\footnotetext{
* Development Research Group, World Bank, 1818 H Street, N.W., Washington, DC 20433, USA, email: afernandes@worldbank.org. This paper draws on a background paper prepared for the World Bank 2006 report "Bangladesh: Strategy for Growth and Employment." I thank Thorsten Beck, Sandeep Mahajan, Luis Serven, and seminar participants at the Dhaka workshop on "Bangladesh: Strategy for Growth and Employment” and at the South Asia Brown Bag Lunch for comments.
} 


\section{Introduction}

A major stylized fact uncovered by the empirical industry evolution literature in developed as well as developing countries is the enormous degree of heterogeneity in productivity across firms even within narrowly defined manufacturing industries (Bartelsman and Doms, 2000; Tybout, 2000). It has also been shown that long-term growth and development across countries is driven to a large extent by productivity growth (Easterly and Levine, 2001). From a policy perspective, it is therefore crucial to understand which factors underlie the heterogeneity in productivity across firms and which are associated with higher productivity.

The literature has proposed various potential determinants of firm productivity. A strand of research has focused on the role of openness and international integration for firm total factor productivity (TFP), following the theoretical insights from the endogenous growth literature. A large number of studies show a beneficial effect of exports on firm TFP (e.g., Kraay, 1999; Blalock and Gertler, 2004; Fernandes and Isgut, 2006). ${ }^{1}$ Another set of studies investigates the effects of foreign ownership on firm TFP (e.g., Arnold and Javorcik, 2005; Kee, 2005). A different literature examines the importance of human capital and training for firm TFP (e.g., Tan and Lopez-Acevedo, 2002; Aw et al., 2005). Yet another literature assesses the impact of research and development (R\&D) activities on firm TFP (e.g., Griliches, 1998). Finally, a recent literature focuses on the role of the business environment for firm TFP (e.g., HallwardDriemeier, et al., 2003; Dollar, et al., 2005). ${ }^{2}$

Our paper contributes to the literature by integrating into a single analytical framework various TFP determinants that have been analyzed separately in previous studies: human capital, integration into world markets, technology, finance, business environment, as well as firm size and age. Using data from a recent survey of manufacturing firms in Bangladesh, we estimate consistent TFP measures for the period

\footnotetext{
${ }^{1}$ See also Wagner (2006) for a thorough review of the literature on exports and productivity.

${ }^{2}$ Similar types of factors have been considered in the macro literature to explain differences in growth across countries.
} 
1999-2003 following Olley and Pakes (1996) and study the determinants of TFP. An important feature of our study is the use of firm-specific output and input price deflators which results in TFP measures that capture true firm efficiency, rather than a mix between firm efficiency and firm market power, as in previous studies. ${ }^{3}$

Bangladesh is an interesting country for our study for two reasons. First, the evidence on the determinants of firm productivity in low-income countries is rare. ${ }^{4}$ Most productivity studies have focused on middle-income countries in Latin America or Eastern Europe due to data availability reasons. Second, the manufacturing sector in Bangladesh is particularly dynamic, having experienced very strong growth since the liberalization of the 1990s in terms of total value-added and exports, largely driven by the ready-made garments sector. ${ }^{5}$

Our main findings are as follows. First, we find an inefficient allocation of resources within the pharmaceuticals, leather/footwear, and textiles industries during the sample period, as less productive firms have a higher share of total industry output. Second, our econometric results identify important determinants of firm TFP, controlling for industry, location, and year fixed effects. Smaller firms are significantly more productive than firms in the largest size category (more than 500 workers). Firm age and TFP exhibit an inverse-U shaped relationship. Firms with a more skilled workforce and more educated or more experienced managers are more productive. Firm TFP benefits from the integration into world markets: foreign-owned firms and exporters have significantly higher TFP. Firms with staff engaged in R\&D activities and firms with quality certifications have higher TFP. However, firms with more advanced technologies improve TFP only in the presence of significant absorptive capacity. While firms with an overdraft facility have significantly higher TFP, firms with access to a bank loan have significantly lower TFP. Power supply problems have a significant negative effect on firm TFP. The presence of crime in industries and locations hurts firm TFP.

\footnotetext{
${ }^{3}$ Bartelsman and Doms (2000) and Katayama et al. (2003) describe the problems associated with TFP measures that rely on output and input measures constructed using industry-specific, rather than firmspecific, deflators.

${ }^{4}$ Dollar et al. (2005) study firm productivity in low-income countries (Bangladesh included) but do not consider a comprehensive set of determinants as they focus on business environment factors.

${ }^{5}$ Since 2000, manufacturing exports represent more than $90 \%$ of total exports of Bangladesh.
} 
The paper is organized as follows. In Section 2, we obtain firm TFP measures and describe briefly the trends in TFP across industries. In Section 3, we examine the determinants of firm TFP. Section 4 concludes.

\section{Obtaining Firm TFP Measures}

\subsection{Data}

Our analysis uses data from a firm survey conducted by the World Bank in Bangladesh between November 2004 and September 2005 in five industries: food, leather/footwear, pharmaceuticals, ready-made garments, and textiles. The sample used in the econometric estimation includes 575 firms, where each firm has at most 5 years of production data. Appendix Table 1 describes the composition of the sample. The majority of firms in the sample belong to the ready-made garments industry. This reflects the importance of the sub-sector in manufacturing in Bangladesh, but also the sample design. ${ }^{6}$ Within ready-made garments, $86 \%$ of firms belong to the woven sub-sector, $21 \%$ belong to the knitwear sub-sector, and 13\% belong to the sweater sub-sector. Most firms in our sample have more than 50 workers, although the size distribution varies significantly across industries. ${ }^{7}$ About a quarter of the firms in the leather/footwear industry are small or medium, i.e., have less than 50 workers. Since our survey covers mostly firms with more than 50 workers, our findings are representative only for the segment of larger manufacturing firms in Bangladesh. Our sample is constituted of relatively young firms, i.e., more than $50 \%$ of firms are less than 10 years old while a third of the firms are 10 to 20 years old. About one-half of the firms are located in Dhaka while 17\% are located in Chittagong (excluding the Export Processing Zones (EPZ)).

\footnotetext{
${ }^{6}$ A sample of 700 firms composed of 350 firms in the ready-made garments industry and 350 firms in the other industries was drawn. Covering $10 \%$ of registered firms in the ready-made garments industry (350 firms) was a condition required for a World Bank (2005) study which financed the survey. Effectively, data was collected for 350 firms in the ready-made garments industry and 332 firms in other industries due to survey non-response for 18 firms. The final sample of 575 firms was obtained after the elimination of firms suffering from data problems, as described in the Appendix.

${ }^{7}$ We adopt the size classification used in the Bangladesh Census of Manufacturing Industries (CMI): "small" firms have less than 10 workers, "medium" firms have between 10 and 50 workers, and "large" firms have more than 50 workers. We divide the large firm category into 3 additional sub-categories: "relatively large" firms have between 50 and 150 workers, "very large" firms have between 150 and 500 workers, and "extremely large" firms have more than 500 workers.
} 
However, the location of firms differs across industries: e.g., firms in the leather/footwear and pharmaceuticals industries are more strongly concentrated in Dhaka.

The survey collected a wealth of information on production variables, firm characteristics, and aspects of the business environment. ${ }^{8}$ Appendix Table 2 shows summary statistics for the main production variables across industries. Firm characteristics differ significantly across industries which is not surprising given the differences in production processes, in the nature of the materials, and in the outputs produced across industries. Firms are largest in the garments industry and smallest in the leather/footwear industry according to the median number of workers. Average sales per firm are highest in the pharmaceuticals industry. Sales per worker are highest in the food industry and lowest in the garments industry. Relative to the average capital stock, real investment is highest in the pharmaceuticals industry (where it represents about $12 \%$ of the capital stock) and lowest in the leather/footwear industry (where it represents only $4 \%$ of the capital stock). Average wages per worker are highest in the pharmaceuticals industry and lowest in the leather/footwear industry. The most striking finding in Appendix Table 2 is the large degree of heterogeneity across firms within any industry, seen in the coefficient of variation of the production-related variables, which is often much larger than one, particularly for investment and capital. In any given industry, at a point in time, there are very different firms - some smaller, other larger, some highly capital-intensive, other labor-intensive - producing similar types of products. Such heterogeneity results in heterogeneity in performance.

\subsection{TFP Estimation}

Firm TFP measures are not observable to the researcher, however they can be obtained as residuals from a production function. For each of the five industries, we estimate the following Cobb-Douglas production function, where output $\mathrm{Y}_{\text {it }}$ is produced by a combination of three inputs: labor $L_{\mathrm{it}}$, materials $\mathrm{M}_{\mathrm{it}}$, and capital $\mathrm{K}_{\mathrm{it}}{ }^{9}$

$$
\ln Y_{i t}=A_{i t}+\beta_{L} \ln L_{i t}+\beta_{M} \ln M_{i t}+\beta_{K} \ln K_{i t}
$$

\footnotetext{
${ }^{8}$ The survey questionnaire shares in common many questions with the World Bank’s Investment Climate Surveys (http://iresearch.worldbank.org/ics/jsp/index.jsp) and is available upon request.

${ }^{9}$ For simplicity, we omit the industry superscript $\mathrm{j}$ from the variables.
} 
$A_{\mathrm{it}}$ is TFP which represents the efficiency of the firm in transforming inputs into output.

Using ordinary least squares (OLS) to estimate the production function coefficients $\left(\beta_{L}, \beta_{M} \beta_{K}\right)$ assumes that input choices are exogenous. However, firm input choices are endogenous. For example, the number of workers hired by a firm and the quantity of materials purchased may depend on unobserved managerial ability, which is part of TFP known to the firm but not observable by the researcher. Since input choices and productivity are correlated, OLS production function estimates are biased. ${ }^{10}$ This endogeneity bias can be partly corrected using fixed effects estimation for the production function, which eliminates unobservable fixed firm characteristics that may affect simultaneously input choices and TFP. However, there may still be unobserved timevarying firm characteristics affecting simultaneously input choices and TFP. We follow the estimation methodology proposed by Olley and Pakes (1996) to correct for the potential simultaneity bias generated by such firm time-varying unobservables. The main idea behind the methodology is that an observable firm characteristic - investment - can be used to proxy for the unobserved firm productivity and estimate unbiased production function coefficients. The Appendix describes the methodology in detail.

The survey includes information on output and inputs, summarized in Appendix Table 2, needed for the production function estimation. Labor is measured by the total number of workers. The capital stock is obtained by cumulating deflated flows of investment using the perpetual inventory method formula. ${ }^{11}$ Output is measured by deflated sales. An important advantage of our measure relative to those used in other studies is that we deflate nominal sales by firm-specific output deflators, which are based on a survey question on annual changes in the price of the firm's main product. Materials is measured by deflated material costs. Again, our measure has the advantage of being deflated by firm-specific materials deflators, which are based on a question on annual changes in the price of the firm's main materials. Previous studies have used industryspecific deflators to obtain the output and materials measures. The problem with that approach can be understood by the following example. Large firms are likely to have market power in product markets and monopsony power in input markets and may thus

\footnotetext{
${ }^{10}$ See Levinsohn and Petrin (2003) for more details on the bias of OLS production function estimates.

${ }^{11}$ Details on the construction of the capital stock are provided in the Appendix.
} 
charge high prices relative to the industry output price and pay lower prices for materials relative to the industry materials price. ${ }^{12}$ Deflating the sales (materials costs) of large firms by the industry output (materials) price will overestimate (underestimate) their output (materials costs). Hence, TFP measures obtained as residuals from a production function estimated using those deflated output and inputs would be overestimated for large firms since they combine true efficiency and price-cost mark-ups. Given the use of firm-specific deflators, our TFP measures capture true firm efficiency. Note also that we implement stringent criteria so that our results are not driven by outliers. ${ }^{13}$

The production function coefficients are shown in Table 1 for OLS, fixed effects, and Olley and Pakes (1996) estimation. These estimates are in line with those from previous studies. The coefficients on materials and labor are highly significant, while that on capital is not significant in some industries. Given the usual measurement problems with the capital stock, this is not surprising. ${ }^{14}$ The Olley and Pakes coefficients on labor (capital) tend to be lower (higher) than those obtained from OLS estimation, indicating the correction of the simultaneity bias. Returns to scale are increasing in all industries. Using the consistent production function coefficients $\left(\bar{\beta}_{L}, \bar{\beta}_{M}, \bar{\beta}_{K}\right)$, we compute timevarying TFP measures for each firm as: $p_{i t} \equiv \ln Y_{i t}-\bar{\beta}_{L} \ln L_{i t}-\bar{\beta}_{M} \ln M_{i t}-\bar{\beta}_{K} \ln K_{i t} \cdot{ }^{15}$

\subsection{Trends in TFP across Industries}

\subsubsection{Industry TFP}

We begin by exploring the dynamics of TFP in our five industries. Figure 1 shows the trends in industry TFP obtained as a weighted average of firm TFP, with weights given by firms' shares in total sales of the industry and year. Since our sample period is short, the findings on industry TFP need to be interpreted as short-run trends in industry

\footnotetext{
${ }^{12}$ These arguments assume that product and input markets do not operate under perfect competition.

${ }^{13}$ See the Appendix for details on the outlier criteria implemented.

${ }^{14}$ The fixed effects estimates of the capital coefficient are generally negative. This is expected as fixed effects estimation relies on within-firm variation over time and thereby exacerbates measurement error problems which are very prominent for capital.

${ }^{15}$ We also obtain TFP measures as residuals from production functions estimated by OLS and by fixed effects. For all industries, our Olley and Pakes TFP measures and the OLS and fixed effects TFP measures are positively and significantly correlated. However, given the aforementioned problems with OLS and fixed effects estimates we do not use the corresponding TFP measures in the rest of the analysis.
} 
performance. Moreover, note that this type of analysis emphasizes the trends in TFP for larger firms, which enter with a larger weight in the calculation of industry TFP.

The dynamics in TFP differs enormously across industries. In the pharmaceuticals, food, and leather/footwear industries, TFP increases in the earlier part of the period, then declines, and finally recovers strongly in 2003. In contrast, in the ready-made garments industry, TFP declines in 1999-2000 and then stagnates until 2003. In the textiles industry, TFP increases in 1999-2002 but declines sharply in 2003. ${ }^{16}$ Figure 1 also shows the evolution of average labor productivity across industries. ${ }^{17}$ While the movements in labor productivity track closely those in TFP for the pharmaceuticals, ready-made garments, food, and leather/footwear industries, the opposite is verified for the textiles industry.

Year-to-year fluctuations in industry TFP need to be viewed with caution. Such fluctuations can be due to short-run factors such as a very large demand shock experienced by some firms in a given year. If the ensuing sales increase is not persistent and does not result in changes of firms' production structures, then the demand shock results in a peak in TFP in a single year. To mitigate these problems, we focus in Table 2 on the average growth rates in industry TFP and labor productivity over the 1999-2003 period. Relative to growth rates of TFP observed across countries - often less than 1\% per year - some of our industry TFP growth rates are relatively high, which could be due to data idiosyncrasies, despite our careful elimination of extreme values from the sample. Hence, we focus on the direction, rather than on the magnitude, of the changes in TFP in Table 2. Our evidence suggests that from 1999 to 2003 TFP improved on average in the pharmaceuticals, food, and leather/footwear industries, but declined in the ready-made garments and textiles industries.

\footnotetext{
${ }^{16}$ TFP dynamics in the woven sub-sector is similar to the dynamics in ready-made garments as a whole. That is not the case in (i) knitwear, where TFP increases until 2001, then declines, but recovers in 2003, and (ii) sweater, where TFP increases throughout the sample period.

${ }^{17}$ Note the large difference in units and scale for TFP (left axis) and labor productivity (right axis) which implies that the changes in labor productivity are much larger in relative terms than those in TFP.
} 


\subsubsection{Average and Median Firm TFP Growth across Industries}

The analysis in the previous section examined industry TFP growth based on weighted averages of firm TFP across industries. ${ }^{18}$ That analysis informs policy-makers and researchers about the trends in TFP for larger firms. However, it is also - perhaps more - interesting to understand the trends in TFP growth for the "average" firm and for the "median" firm in each industry. In Table 3, we document the changes in average and median firm TFP growth across industries. ${ }^{19}$ This approach gives the same weight to each firm within each industry. Moreover, the analysis of median TFP growth is more robust to the presence of extreme values. The findings using this approach differ significantly from those in the previous section for industry TFP.

Table 3 shows that, as expected, median TFP growth is generally smaller (in absolute value) than average TFP growth. ${ }^{20}$ While in the pharmaceuticals and food industries the distribution of TFP growth rates is skewed to the left (i.e., some very negative TFP growth rates push the average TFP growth rate below the median TFP growth rate), the opposite is verified in the ready-made garments, leather/footwear, and textiles industries. Figure 2 shows that in the pharmaceuticals and ready-made garments industries, median firm TFP growth rates are negative in 1999-2001 and become positive starting in 2002. ${ }^{21}$ In contrast, in the food, leather/footwear, and textiles industries, median firm TFP growth rates are generally positive over the sample period, and are particularly high in the leather/footwear industry.

Figure 2 also shows median firm growth rates of output and inputs across industries. Median output growth rates are positive and high in the pharmaceuticals industry throughout the period. In contrast, they are negative in the food, leather/footwear, and textiles industries and very close to zero in the ready-made garments industry until 2002, but increase to about 5\% in all four industries in 2002-

\footnotetext{
${ }^{18}$ Note that we use the expression "growth rates" to designate both positive and negative changes in TFP.

${ }^{19}$ The median firm TFP growth rate in an industry and year is the growth rate such that half the firms in that industry and year have lower TFP growth rates and half the firms have higher TFP growth rates.

${ }^{20}$ While the more extreme values of TFP growth do not affect the magnitude of median TFP growth, they strongly influence average TFP growth.

${ }^{21}$ Median TFP growth in the sweater sub-sector is positive during the period and thus differs from the evolution for ready-made garments as a whole.
} 
2003. ${ }^{22}$ The three inputs exhibit different dynamics throughout the sample period. Median employment growth is positive in all industries in 1999-2003, and is highest in the pharmaceuticals and ready-made garments industries, with growth rates of about 3\% per year. ${ }^{23}$ Overall, there is evidence of an expansion in the workforce of firms across industries during the sample period. The median growth in materials is positive in all industries in 2002-2003 but is negative in all but the pharmaceuticals industry in years prior to 2002. The trends up to 2002 could signal cheaper raw materials becoming available to firms. Finally, the median growth rates of the capital stock are negative and large in magnitude - between - $5 \%$ and $-10 \%$ - in all industries. This negative trend is due to the fact that, in all industries, many firms make only small investments during the sample period. ${ }^{24}$ Such small investments are not sufficient to compensate for depreciation and thus the median capital stock declines over time. Increased capacity utilization rates during the sample period are a potential rationale for this decline. If firms have overinvested in the 1990s, as aggregate data on investment flows in Bangladesh suggests, after 1999 they could be making more intensive use of their existing machines instead of purchasing new machines. For firms in our sample, capacity utilization increases from an average of $79 \%$ in 2002 to an average of $80 \%$ in $2003 .{ }^{25}$ In the pharmaceuticals industry, the increase is stronger - from $65 \%$ to $69 \%$ in $2002-2003$ - and may account for the large increase in TFP in that industry shown in Figure 1.

The findings in Sections 2.3.1.-2.3.2 are based on a sample of manufacturing firms, rather than a full census of manufacturing firms in Bangladesh. Given the size distribution of firms in our sample, we can only claim that our findings on TFP growth rates are representative of the growth rates for larger manufacturing firms.

\subsubsection{Industry TFP and Allocative Efficiency}

For any given industry and year, aggregate TFP may grow (decline) because all firms become more (less) productive or because output is reallocated towards the more (less) productive firms. Olley and Pakes (1996) propose an interesting decomposition of

\footnotetext{
${ }^{22}$ Within the ready-made garments industry, median output growth is positive and very strong in knitwear and sweater in all years but is negative in woven until 2002.

${ }^{23}$ Within the ready-made garments industry, median employment growth is highest in knitwear.

${ }^{24}$ Average and median real investment rates are shown in Appendix Table 2.

${ }^{25}$ The survey did not collect data on capacity utilization rates prior to 2002.
} 
industry weighted average TFP into two components: (i) industry unweighted average TFP and (ii) a term measuring the covariance between firms' shares in total sales and firms' TFP. ${ }^{26}$ The covariance term measures allocative efficiency: if it is positive, then the more productive firms in the industry have higher market shares and the allocation of resources is efficient. ${ }^{27}$

Figure 3 shows the decomposition of industry TFP into the two aforementioned components for each industry. The sign of the covariance term varies across industries. While in the ready-made garments industry the covariance term is positive in 1999-2003, it becomes positive in the food industry only after 2001. In the pharmaceuticals, leather/footwear, and textiles industries, the covariance term is negative, suggesting that in these industries less productive firms have a higher share of output. To be precise, in the leather/footwear industry, the covariance term is close to zero, which implies that there is essentially no correlation between firms' TFP and firms' shares in total sales in that industry. Overall, the decompositions of industry TFP suggest that in the pharmaceuticals and textiles industries, and to a lesser extent the leather/footwear industry, the distribution of output across firms is not efficient. This inefficiency may be related to the lack of competition - perhaps import competition - or to bankruptcy rules and the lack of markets for used capital that prevent the exit of less productive firms. Some unproductive firms may have been shielded from competition in Bangladesh, remained in business and grew large (in terms of output), although, for efficiency purposes, the industry would be better off selling those firms' assets and reallocating their market shares to more productive firms.

We should note, however, that most TFP growth and decline across industries is accounted for by growth and decline in the unweighted average firm TFP, not by the reallocation of output across firms. Also, the negative reallocation terms are not systematically related to the direction of industry TFP growth in the leather/footwear and textiles industries. In the food industry, however, the switch from an inefficient to an

\footnotetext{
${ }^{26}$ The formula for the decomposition is shown in the Appendix.

${ }^{27}$ This positive statement has no normative content. There may be reasons why a reallocation of output to less productive firms that are, e.g., more socially or environmentally responsible, could increase economic welfare. Here, we consider only the efficient allocation of resources (output) to their more productive use.
} 
efficient resource allocation in 2001 is associated with strong positive TFP growth in that year.

The use of these decompositions illustrates the importance of using the Olley and Pakes (1996) methodology to correct for the endogeneity of input choices with respect to TFP. We also calculated a weighted average industry TFP based on the OLS production function estimates and decomposed into the two aforementioned terms. According to this decomposition, the covariance term is positive in most industries and years, suggesting an efficient allocation of resources. However, the OLS coefficient on capital tends to be underestimated which leads to an overestimation of TFP OLS for firms with large capital stocks. Since firms with large capital stocks generally have large sales and market shares, the covariance term between TFP OLS and market shares is erroneously high. Using the Olley and Pakes (1996) coefficient on capital, TFP is not overestimated for firms with large capital and large sales, and thus the more realistic covariance term derived turns out to be negative for some industries.

\section{Determinants of Firm TFP}

\subsection{Empirical Framework and Econometric Problems}

This section examines the determinants of firm TFP in Bangladesh, considering a comprehensive set of policy-relevant factors which are considered in different strands of the literature but have generally not been integrated into a single analytical framework. We study how each of the following factors - human capital, integration into world markets, technology, finance, and the business environment - promote or constrain firm TFP. In addition to these factors, we also focus on the role of firm size and age. With $i$ designating a firm, $t$ a year, $j$ an industry, and $r$ a location, the empirical reduced-form specifications that we estimate are given by:

$$
p_{i t}=\beta_{1} X_{1 i r t}^{j}+\beta_{2} X_{2 i r t}^{j}+\beta_{3} X_{3 i r t}^{j}+\beta_{4} X_{4 i r t}^{j}+\beta_{5} X_{5 i r t}^{j}+\beta_{a} a g e_{i r t}^{j}+\beta_{s} s i z e_{i r t}^{j}+I^{j}+I^{t}+I^{r}+\varepsilon_{i r t}^{j}
$$

where $X_{1 i r t}^{j}$ is a vector of human capital variables, $X_{2 \text { irt }}^{j}$ is a vector of variables related to the integration into world markets, $X_{3 i r t}^{j}$ is a vector of technology variables, $X_{4 i r t}^{j}$ is a 
vector of finance variables, $X_{5 \text { irt }}^{j}$ is a vector of business environment variables, $I^{j}, I^{t}$, and $I^{r}$ are industry, year, and location fixed effects, respectively.

Our estimation suffers from several potential econometric problems and consequently our results need to be interpreted with caution. First, there is a problem of endogeneity for several of the aforementioned factors. The direction of causality may actually run from TFP to a given determinant. For example, if we find that exporters are more productive, it is not fully clear whether it is the fact that firms export that leads to higher TFP or it is the case that firms with higher TFP are those able to break into export markets. In theory, such problems could be solved if we had instrumental variables correlated with the TFP determinants but not with TFP. In practice, such variables are not available, particularly given the large number of factors considered in our analysis. Our approach to deal with the endogeneity problem is to include in our regressions industry, location, and year fixed effects, firm age, and firm size. These variables control for potential unobserved factors that may affect the determinants of TFP and TFP itself. The impact of the TFP determinants that is estimated when all control variables are included is more likely to reflect causality from the determinants to firm TFP. For business environment factors, our approach takes an additional step. We include in our regressions averages of the business environment variables at the industry-location level, instead of including business environment variables at the firm-level. The rationale for this approach is that the business environment is likely to be similar for firms in given industry and location. Moreover, it is plausible to assume that for an individual firm the business environment in its industry and location is exogenous.

Second, given the large number of potential determinants of TFP, our regressions may suffer from a multicollinearity problem. If some of the determinants are correlated, the results from the regressions including many determinants can be difficult to interpret. Our approach to address this problem is to also estimate regressions that include a single determinant at a time along with basic control variables (industry, location and year fixed effects, firm age and size). Such regressions do not suffer from the multicollinearity problem but suffer from an omitted variables' problem. If the effect of a given determinant on firm TFP is qualitatively similar in both the regressions that include all 
determinants and the regressions that include only that determinant, we have more confidence on the sign and significance of its effect on TFP.

Third, our specifications suffer from the fact that many of the determinants of TFP are available for each firm in a single year, while TFP is available for four or five years. For estimation purposes, we assume that those determinants are constant over the sample period. While this is a relatively safe assumption for business environment variables, it may be somewhat restrictive for other variables such as, e.g., human capital or technology-related variables. The lack of variability over time in some determinants works against our finding of significant effects, as the variability would help identify their effect on firm TFP. Also, note that the lack of time variability in many of the determinants prevents us from using fixed effects estimation. Instead, we estimate all our specifications by OLS but we include a rich set of control variables to account for unobserved factors potentially influencing TFP and its determinants.

\subsection{Determinants of Firm TFP}

We now briefly discuss the measures for the five types of determinants of firm TFP considered in the econometric analysis.

\section{1) Human Capital}

The human capital factor is measured by the education and experience of the manager, and by occupation-based as well as education-based measures of workforce skills. Panel A of Appendix Table 3 describes the human capital characteristics of firms in our sample. In the pharmaceuticals, food, and textiles industries, more than $70 \%$ of firms are run by managers with post-graduate education. However, that percentage is much smaller in the ready-made garments and leather/footwear industries. The lower educational achievement of managers in the leather/footwear industry may be compensated by their longer work experience: 16.4 average years of experience relative to only 8.2 in the ready-made garments and textiles industries. In contrast to the often highly educated managers, college-educated workers represent a very small percentage of total workers, ranging from $3.2 \%$ in the footwear/leather industry to $24.4 \%$ in the pharmaceuticals industry. These figures reflect the poor average educational achievement in Bangladesh: 2.6 years of education for the population as a whole in 2000 according to 
Barro and Lee (2000) statistics. In contrast, skilled workers - the sum of professional, technical, administrative, managerial, and skilled production workers - represent more than $60 \%$ of total workers in all but the pharmaceuticals industry. There seems to be a very important distinction between an educated workforce, which is lacking in all industries, and a skilled workforce, which is available in all industries. The difference in summary statistics for occupation-based versus education-based measures of skills is explained can be explained by skilled production workers. Production workers are a large fraction of the workforce in many firms and are likely to be proficient at what they do by virtue of experience or ability but they do not necessarily - most often don't - have a large number of formal years of education.

\section{2) Integration into World Markets}

Firms can be internationally integrated by virtue of ownership or by selling their products in foreign markets. Panel B of Appendix Table 3 shows the summary statistics for foreign ownership and exports. Foreign-owned firms represent about $10 \%$ of our sample. However, the leather/footwear industry has a much smaller proportion (4.2\%) of foreign-owned firms. Export orientation varies significantly across industries. While virtually all firms in the ready-made garments industry and $91.7 \%$ of the firms in the leather/footwear industry are exporters, only $26 \%$ of firms in the pharmaceuticals industry export. In the ready-made garments and leather/footwear industries, most of the firms are majority exporters, i.e., they sell more than $50 \%$ of their output in export markets. In contrast, in the pharmaceuticals industry there are no majority exporters. Finally, firms in the garments and footwear/leather industries have on average a much longer experience in export markets than firms in other industries. ${ }^{28}$

\section{3)}

\section{Technology}

Technological progress is often measured by TFP growth for lack of more direct measures. In this paper, however, we rely on observable measures of technology. Measures such as the percentage of computerized machinery and the percentage of new

\footnotetext{
${ }^{28}$ We use detailed information to construct the export experience variable. The survey asks the year since when a firm has exported, whether and in which year the firm has interrupted exports and if the firm interrupted exports, in which year exports restarted.
} 
machinery (less than 5 years old) reflect directly technology embodied in installed equipment, whereas measures such as a dummy variable for firms with staff engaged in $R \& D$ activities and a dummy variable for firms that have been awarded one or more quality certifications (e.g., ISO) are more indirectly related to technological factors. Panel C of Appendix Table 3 shows summary statistics for the technology measures. Firms in the ready-made garments and footwear/leather industries operate on average with very small fractions - less than $10 \%$ - of computerized machinery. In contrast, in the pharmaceuticals industry that average is $41.9 \%$. While in the garments and textiles industries $50 \%$ of the machinery used is less than 5 years old on average, that percentage is less than $40 \%$ in the pharmaceuticals and food industries and much lower - less than $20 \%$ - in the leather/footwear industry. Except for the pharmaceuticals industry, in all other industries, less than $20 \%$ of firms have staff devoted to R\&D activities. Finally, the percentage of firms with quality certifications varies substantially across industries: it is highest in the pharmaceuticals industry and lowest in the leather/footwear industry.

\section{4) Finance}

To address the role of financial constraints for firm performance, we use several measures: a dummy variable for firms having an outstanding loan, a dummy variable for firms with an overdraft facility or line of credit, and the percentages of working capital and of investments financed by banks and related institutions. ${ }^{29}$ Panel D of Appendix Table 3 shows summary statistics for the finance variables. In all but the ready-made garments industry, more than $60 \%$ of firms report having an outstanding bank loan. Also, in all industries more than $60 \%$ of firms have an overdraft line of credit. However, less than $50 \%$ of working capital and less than $30 \%$ of investments are financed by banks and related institutions on average. In particular, the firms in the footwear/leather industry finance only $6.3 \%$ of their investments by banks and related institutions, while firms in the ready-made garments industry finance only $16.3 \%$ of their working capital by banks and related institutions.

\footnotetext{
29 "Financed by banks and related institutions" consists of financing by domestic commercial banks, international commercial banks, leasing arrangements, special development financing, public financing (government agencies) or other public services.
} 
The business environment corresponds to the institutional, policy, and regulatory environment in which firms operate. While most previous studies relied on managerial opinions and perceptions about the business environment, our survey has the advantage of including objective measures that capture institutional and policy weaknesses affecting firms. Our measures cover different dimensions of the business environment. Bureaucracy and government efficiency in providing services are captured by the number of days needed to clear customs for imports and the percentage of weekly time spent by managers dealing with regulation. The reliability of the public infrastructure is captured by the number of power outages suffered and a dummy variable for firms that have a generator. Corruption is captured by a dummy variable for whether firms in a given industry pay bribes to government officials to "get things done" and the percentage of sales paid as bribes. Finally, potential crime is captured by protection payments made as a percentage of firm sales. ${ }^{30}$

The aforementioned business environment measures cover the major obstacles to growth and operations faced by manufacturing firms in Bangladesh, as revealed by perceptions' data. ${ }^{31}$ Specifically, the major obstacles pointed out by firms are (a) corruption (65\% of firms), (b) customs (63\% of firms), (c) power from the public grid (44\% of firms), (d) business licensing and operating permits (22\% of firms), frequent changes in government regulation and regulatory policy (16\% of firms), and other bureaucracy-related aspects (e.g., fire department or environmental permits). Although crime is not among the top obstacles, it is crucial for $13 \%$ of firms. We are confident to be covering the most crucial aspects of the business environment for firms in Bangladesh, however our TFP regressions could suffer from an omitted variables' problem if other relevant obstacles are not accounted for because they were not included in the list of issues covered by the survey questionnaire.

\footnotetext{
${ }^{30}$ In the survey questionnaire, (i) "get things done" was explained as bribes needed for firms to resolve issues related to customs, taxes, regulations, and services and (ii) protection payments are those to organized crime to prevent violence. We use firm values for the ratio of protection payments to sales in the regressions.

${ }^{31}$ Firms in Bangladesh were asked to rank 28 business environment issues according to their degree of obstacle to firm operations and growth. The results from these rankings are available upon request.
} 
Panel E of Appendix Table 3 shows summary statistics for the business environment measures. Across industries, it takes between 3 and 5 days to clear customs for imports. The percentage of time spent by managers dealing with regulation and bureaucracy varies from $18.2 \%$ in the textiles industry to $27 \%$ in the leather/footwear industry. The number of power outages experienced by firms in the year before the survey is very large for firms in all industries. Firms in the food and leather/footwear industries are particularly affected by the weaknesses of the electricity supply, suffering on average 560 and 885 power outages per year, respectively. In face of the frequency of power outages, it is not surprising that more than $80 \%$ of firms in all industries own a generator. There is evidence of high levels of corruption in the interactions of Bangladeshi firms with government officials and bureaucracy. More than $85 \%$ of firms indicate that in their industry it is necessary to pay bribes to government officials to get things done. Such bribes amount to $1.3 \%$ of sales on average in the ready-made garments industry but are only half as large in other industries. Finally, while firms spend relatively little resources on protection payments on average, there is a large degree of variability in those expenses across firms.

\subsection{Main Results}

In this section, we discuss our findings on the determinants of firm TFP. As mentioned earlier, Eq. (2) may suffer from a multicollinearity problem since it includes multiple determinants of TFP that may be correlated. To address this problem, we show in Appendix Table 4 the results from regressions of firm TFP on a single determinant at a time, in addition to basic controls. The sign and significance of the effects in those regressions are similar to those in the regressions including multiple determinants. Thus, the concern of a multicollinearity problem is mitigated.

We focus first on the role of firm size and firm age for TFP. Theoretical models of industrial dynamics with firm heterogeneity predict that more productive firms are larger (Jovanovic, 1982). Also, several stylized facts have been established for developed countries on the impact of the life-cycle on manufacturing firms' TFP (Bartelsman and Doms, 2000). Studies based on U.S. data find that firms generally enter an industry with a small size and low productivity. The firms that survive grow and converge quickly to 
the average size and productivity in the industry. It is not clear whether in a low income country like Bangladesh, the same type of stylized facts holds. Our analysis is a first step in uncovering the effects of life-cycle on TFP for manufacturing firms in Bangladesh. In Table 4, we find that, relative to the extremely large-sized firms (more than 500 workers), firms of smaller sizes are more productive. ${ }^{32}$ Specifically, medium-sized firms (10-50 workers) are the most productive firms, on average 32\% more productive than extremely large-sized firms. The size category for which the TFP advantage relative to extremely large-sized firms is smaller is the very large-sized firms (150-500 workers). This finding is robust across specifications. In unreported regressions where firm size enters as a continuous variable measured by total employment, we also obtain the same qualitative result, i.e., larger firms have lower TFP. While total employment is a commonly used measure of firm size, one can argue that a firm's total capital stock is a better measure of size. Our findings are also robust to the use of the capital stock as the measure of firm size. Thus, in Bangladesh the larger firms are not the most productive. In fact, firms that are too large may suffer from inefficiencies in terms of coordination, management, and supervision resulting from poor corporate management and a lack of qualified middle managers. ${ }^{33}$ Our findings are broadly in line with those for other developing countries for which there is no evidence of a strong size disadvantage for firm productivity (Tybout, 2000). ${ }^{34}$

An important remark should be made at this stage. Our sample is skewed towards larger firms and includes only a small number of small firms. The small firms included are likely to be particularly efficient since they have survived and are part of the same business associations as the "bigger players" in their industry. Thus, the focus of our findings on size and TFP should be on the comparison across size categories for mediumsized and particularly for large-sized firms (i.e., those with more than 50 workers). The

\footnotetext{
${ }^{32}$ In Tables 4-5, the number of observations in each regression (each column) differs as it depends on the number of firms that have non-missing values on all the determinants of TFP included.

${ }^{33}$ Anecdotal evidence from conversations with firm managers suggests that this problem is particularly serious in Bangladesh.

${ }^{34}$ Van Biesebroeck (2005) finds that TFP increases monotonically with size for firms in nine African countries. However, since he classifies as large all firms with more than 100 employees, we cannot establish a direct comparison of our results with his. In our sample such firms can belong to (i) the relatively large size category, (ii) the very large size category, or (iii) the extremely large size category, and (i) exhibits much higher TFP than (ii) or (iii).
} 
findings on firm size and TFP suggest that firms with the largest market shares have low productivity and thus help rationalize the findings in Section 2.2.3 of an inefficient allocation of resources in several industries.

Our findings suggest an inverse-U shaped relationship between firm age and TFP that is very robust across specifications. A clear ranking of firm TFP across age categories can be established. The most productive firms are those that are either 10-20 years old or 20-40 years old, followed by firms that are 5-10 years old, then by firms that are more than 40 years old, and finally by firms that are less than 5 years old. ${ }^{35}$ This inverted U-shaped life-cycle pattern suggests that firms start at low TFP while they are young, then they learn e.g., by doing, by undertaking new investments, by participating in international markets, or by realizing economies of scale as they age which can increase TFP. After a certain age - around 40 years old in our sample - their technology, modes of production and operations likely become outdated and their TFP advantage erodes.

Our findings are broadly consistent with the predictions from industrial evolution models of young firms entering the industry at low productivity then growing and converging to the average productivity in the industry. Our findings for the monotonically increasing part of the inverted U-shape relationship between age and TFP are consistent with evidence for firms in the U.S. (Jensen et al., 2001) and in African countries (Van Biesebroeck, 2005) ${ }^{36}$ However, the empirical studies provide no evidence of the declining part of the inverted U-shape relationship. Jensen et al. (2001) estimate a strictly linear relationship between age and TFP and Van Biesebroeck (2005) does not decompose its older age group (firms aged '20 or more years') into additional categories - 20-40 years old and more than 40 years old, as our study does.

Next, we discuss the findings on the five types of determinants of TFP described in Section 3.2. We should note that these five types of determinants are very relevant for firm TFP, they account for about $70 \%$ of variation in firm TFP and they are jointly as well as separately (each of the 5 types) significant in all the specifications.

\footnotetext{
${ }^{35}$ In unreported regressions that allow for a non-linear relation between age and TFP (including age and age squared as continuous variables), we find that TFP increases with firm age but at a decreasing rate.

${ }^{36}$ Both studies find that TFP is higher for firms belonging to younger age groups relative to firms belonging to older age groups.
} 
We find an important impact of the quality of the firm's human capital on TFP. Firms which employ a higher fraction of skilled workers are significantly more productive. In unreported regressions, we also find that firms with a higher fraction of college-educated workers have higher TFP. Firms with more experienced and more educated managers are more productive than other firms. These results point out to the importance of human capital formation for the performance of manufacturing firms. ${ }^{37}$

The findings on the role of manager quality for firm TFP are interesting per se, but they also strengthen our findings on the other determinants of TFP. Our econometric specifications suffer the following potential endogeneity problem that better managers lead their firms to achieve higher TFP but simultaneously influence some of the determinants of TFP such as, e.g., exports, skills of the workforce, or access to finance. Since our regressions control for managerial education and experience, we argue that the effects of other determinants on TFP are not driven by unobserved managerial ability.

The results in Table 4 show the important benefits for firm TFP of integration into world markets. Firms with foreign ownership are about 10\% more productive than other firms. This finding is obtained in regressions that control for industry, location, and year fixed effects, and hence is not driven by macroeconomic fluctuations (i.e., business cycles in the FDI-sending countries could make some years more prone to foreign investment), nor by a composition effect (i.e., certain industries are more prone to receive FDI), and it is also not driven by a location effect (i.e., FDI firms are more likely to locate in certain regions such as EPZs). ${ }^{38}$ Our findings suggest that foreign-owned firms in Bangladesh have an advantage in terms of both tangible assets (e.g., better technology) as well as intangible assets (e.g., better access to distribution and marketing channels and networks) relative to domestically-owned firms.

Our findings also highlight very important benefits of exporting for firm TFP. In columns (1) and (4) of Table 4, the regressions include a dummy variable identifying firms engaged in export markets whose estimated effect on TFP is positive and

\footnotetext{
${ }^{37}$ Our findings on the importance of manager education and experience are qualitatively similar to those in Burki and Terrell (1998) and in Lall and Rodrigo (2001) for firms in Pakistan and in India, respectively, despite methodological differences relative to our study in the estimation of productivity. Both studies use data envelopment analysis to obtain efficiency measures for firms.

${ }^{38}$ Our findings mirror those obtained by Kee (2006) using a subsample of our dataset for the ready-made garments industry.
} 
significant. The regressions in columns (2) and (5) of Table 4 include a dummy variable identifying only firms that export the majority of their output. One could argue that firms which export a small percentage of their output are only marginally involved in exporting and thus have less scope for learning and receiving all the benefits from the participation in export markets. However, the results in columns (1) and (4) are quite similar to those in columns (2) and (5) and show that, within industries and locations, exporters - whether they are majority or not - are 9 to $10 \%$ more productive than non-exporters. The TFP advantage of exporters may be due to technological learning from foreign buyers but also to the possibility that exporters improve their own technological capabilities in order to exploit profitable opportunities in export markets. ${ }^{39}$ This strong positive association between TFP and the participation in export markets could reflect a self-selection of better firms into export markets, rather than the effect of exporting on TFP. ${ }^{40}$ Selfselection and learning-by-exporting are not mutually exclusive hypotheses though, as firms with high TFP that can afford the sunk costs of entry into export markets may continue to improve TFP as a result of their exposure to exporting. Exporters face several challenges that likely result in learning-by-exporting and consequent improvements in firm TFP. Exporters need to solve new problems such as adopting stringent technical standards to satisfy more sophisticated consumers, or introducing more efficient machinery. Moreover, exporters are more pressured to meet orders in a timely fashion and ensure product quality for export markets that are more competitive than the domestic market. To better examine the presence of learning-by-exporting effects on firm TFP in Bangladesh, we follow Fernandes and Isgut (2006) and include in the regressions in columns (3) and (6) of Table 4 a measure of export experience - the number of years that a firm has exported - instead of export participation measures. Firms with longer experience in export markets have significantly higher TFP.

Table 4 shows that firms with staff engaged in R\&D activities have significantly higher TFP. It may seem inadequate to talk about R\&D activities for firms in Bangladesh

\footnotetext{
${ }^{39}$ Westphal (2002) documents the latter possibility for firms in Taiwan.

${ }^{40}$ The self-selection hypothesis is more likely to be verified if entry into export markets is characterized by economically significant sunk costs, such that only the firms with higher TFP are able to export. These sunk costs have been shown to be empirically relevant (Roberts and Tybout, 1997).
} 
given the very low overall R\&D expenditures in the country. ${ }^{41}$ However, we do not interpret R\&D as activities bringing breakthrough patentable innovations. Rather, R\&D activities in Bangladeshi firms are likely to consist in low-level activities related to the adaptation of technology and production processes to local conditions. The evidence suggests that such low-level R\&D activities are actually crucial for TFP improvements. Similarly, quality certifications are positively and significantly associated with firm TFP. Quality certifications such as ISO guarantee the use of internationally recognized technical standards and are an important means for firms to acquire state of the art technological know-how and raise their capability to compete on global markets.

Firms producing with a larger fraction of new machinery (less than 5 years old) are significantly less productive than firms using older machinery. Also, firms operating with a larger share of computerized machinery have significantly lower TFP. These two findings on the impact of technology factors on firm TFP are counter-intuitive in light of the widely accepted idea that the accumulation of knowledge is a key determinant of TFP. Measurement problems may be to blame. While our direct measures of technology proxy for the sophistication, quality, and efficiency of the machines and production processes used by the surveyed firms, they leave much unmeasured, namely the intangible capital components of technology. We exploit further the role of technologyrelated factors by considering the interaction between $R \& D$ and technology in their effect on firm TFP. As Cohen and Levinthal (1989) argue, R\&D activities perform two roles: (i) they stimulate innovation but also - and possibly more importantly in the case of Bangladesh - (ii) they develop a firm's ability to identify, assimilate and exploit outside knowledge. Table 5 shows the results from estimating a variant of Eq. (2) where we allow the technology measures to enter separately and interacted with the dummy variable identifying firms that staff engaged in $R \& D$ activities. In columns (1)-(3), we show that although firms with a larger percentage of new machinery have lower TFP, that effect is counteracted when firms engage in $R \& D$ activities. In columns (4)-(6), we find that while computerized machinery is associated with significantly lower TFP, the coefficient on the interaction between computerized machinery and the dummy variable

\footnotetext{
${ }^{41}$ Mahajan (2005) documents that R\&D expenditures represent 0.03\% of GDP in Bangladesh, compared to $0.7 \%$ in China and India, and $0.2 \%$ in the Philippines.
} 
for R\&D staff is positive and significant. However, the implied marginal effects of new machinery and computerized machinery on firm TFP evaluated at the sample mean of the $\mathrm{R} \& \mathrm{D}$ staff dummy are still negative. ${ }^{42}$

These findings suggest that more advanced technologies - newer or computerized - per se may not bring TFP benefits unless firms possess sufficient absorptive capacity (e.g., by having personnel engaged in R\&D activities) that allows them to exploit and fully benefit from the potential efficiency improvements associated with such technologies. Our findings are consistent with those obtained at the cross-industry level in OECD countries by Griffith et al. (2004). Finally, note that the negative effects of advanced technology on firm TFP may reflect the fact that firms using new or computerized machinery are undergoing a learning process and may be operating the technology inefficiently because skills and experience are only being gradually built, even though the technology may be productivity-enhancing once it reaches its optimal use. $^{43}$ Our findings are in line with those in Sakellaris (2004) of a productivity decline associated with new technology adoption by U.S. manufacturing plants.

Table 4 shows that firms with an overdraft facility or credit line have significantly higher TFP. In contrast, firms with access to a bank loan have significantly lower TFP. In our sample, access to loans and overdrafts is more common among relatively large-sized firms than among smaller firms. ${ }^{44}$ In fact, there is widespread evidence of a correlation between firm size and access to finance. ${ }^{45}$ However, our finding that firms with access to a bank loans have lower TFP is also obtained when we reestimate the regressions excluding size. Thus, the negative effect of the loan dummy is not driven by the correlation between firm size and access to finance. In unreported regressions, we also find a negative correlation between the percentage of new investments financed by banks and related institutions and firm TFP but a positive

\footnotetext{
${ }^{42}$ The implied marginal effect of new machinery (computerized machinery) is equal to the coefficient on the percentage of machinery less than 5 years old (computerized machinery) plus the product of the coefficient on the interaction term and the average of the R\&D staff dummy.

${ }^{43}$ Qualitative similar results to those shown in Table 5 are obtained when using the share of collegeeducated workers as the measure of worker human capital. Note that regardless of how the technology variables are entered the findings on other determinants of TFP are similar across Tables 4 and 5.

${ }^{44}$ However, access to bank finance is more common among relatively large-sized firms than among very large-sized firms (the largest size category).

${ }^{45}$ Size is often a proxy for financing constraints (Beck, Demirgüç-Kunt, and Maksimovic, 2005).
} 
correlation between the percentage of working capital financed by banks and related institutions and firm TFP. Finally, if there is a strong correlation between the overdraft dummy and the loan dummy, the findings on access to finance and firm TFP could be driven by multicollinearity. While there is some overlap between the firms with an overdraft and the firms with a loan, we still find a positive effect of the access to an overdraft facility and a negative effect of the access to a bank loan on firm TFP in unreported regressions that include only one of the variables measuring access to finance. ${ }^{46}$ Interestingly, Van Biesebroeck (2005) finds a similar positive association between access to overdrafts and TFP and a negative association between access to loans and TFP for firms in Africa. Overall, our findings suggest that access to short-term finance - such as that provided by an overdraft facility or a line of credit to address working capital and day-to-day business needs - has a positive impact of TFP, while the access to long-term finance has a negative effect on TFP. These surprising findings may reflect inefficiencies of the banking sector in Bangladesh and deserve further analysis beyond the scope of this paper. However, they should by no means be taken as evidence that access to external finance is not relevant for firm performance.

Turning to business environment factors, Table 4 shows the crucial obstacle for firm TFP posed by poor infrastructure in Bangladesh. Firms in industries and locations experiencing a larger number of power outages in a year have significantly lower TFP. The coefficient in column (2) suggests that a firm belonging to an industry and location with $1 \%$ more power outages than other industry-location cells, has more than $8 \%$ lower TFP. $^{47}$ It is possible that poor electricity supply hurts less strongly those firms that have purchased a generator. In columns (4)-(6) of Table 4, we show the results from estimating a variant of Eq. (2) where we allow the number of power outages to affect TFP individually and interacted with a dummy for firms owning a generator. The results show that the TFP of firms owning a generator suffers actually more due to power outages than the TFP of firms that do not own a generator. ${ }^{48}$ Overall, we can confidently conclude that

\footnotetext{
${ }^{46}$ The correlation between overdraft and loan dummies is 0.18 , significant at the $1 \%$ confidence level.

${ }^{47}$ Since the dependent variable in the regressions is the logarithm of TFP, we can interpret the coefficient on the logarithm of the number of power outages as an elasticity.

${ }^{48}$ The effect of power outages for the TFP of firms which own a generator is the sum of the coefficient on the power outages for all firms plus the coefficient on power outages interacted with the dummy for owning a generator.
} 
the constraints to firm TFP posed by poor electricity supply in Bangladesh are extremely severe. Our findings parallel those obtained by Dollar et al. (2005) which study the importance of business environment factors for the TFP of ready-made garments firms in Bangladesh, China, India, and Pakistan. ${ }^{49}$

The results in Table 4 also show an important negative effect of crime on TFP. Firms making larger protection payments are significantly less productive than other firms. We assume that larger protection payments to be "spared" from organized crime are a proxy for an environment with more potential crime. In unreported regressions, we also find a negative effect of the ratio of security expenses to sales when that variable is the measure for crime.

Heavier bureaucracy and red tape in an industry and location seem to be associated with higher firm TFP, according to the estimates in Table 4. While the effects of the number of days taken to clear customs on TFP are very small and insignificant, the effects of the percentage of time that firm managers must spend dealing with regulations on TFP are actually strong and significant. Also, the results in Table 4 suggest that firm TFP is higher in industries and locations where firms pay a larger percentage of their sales in bribes to get things done. In unreported regressions where we include the percentage of firms in each industry-location cell paying bribes to get things done as the measure of corruption, we also find that firm TFP is higher in industries and locations that have a larger fraction of firms paying bribes.

We interpret the findings on bureaucracy and corruption as reflecting reverse causality. First, better performing firms are likely to be more visible to government officials and thus become more subject to inspections or visits. Moreover, firms with higher productivity are likely to be involved in more activities requiring government permits or meetings with officials such as investments for expansion, exports, etc. Second, as argued by Svensson (2003) and Fisman and Svensson (2005) if government officials have discretion in implementing or enforcing regulations, then they will

\footnotetext{
${ }^{49}$ However, our findings differ from those obtained by Hallward-Driemeier, et al. (2003) for Chinese firms in several industries. That study finds no effect of electricity infrastructure on TFP. The difference in results in very likely due to the difference in levels of development of the two countries, and to the fact that physical infrastructure no longer constitutes a bottleneck for growth of Chinese firms, while it is still very relevant for Bangladeshi firms.
} 
customize the amount of harassment on firms to extract bribes and try to extract as high a bribe as possible from firms with a larger ability to pay. Irrespective of their size, more productive firms have a larger ability to pay bribes to cut through bureaucratic hassles, while less productive firms cannot do it. Our positive effect of corruption on firm TFP suggests that indeed the industries and locations with more productive firms are more targeted by government officials, thus the opportunities for bribe-seeking behavior are larger and firms end up paying more bribes. ${ }^{50}$

\section{Conclusion}

This paper uses data from a recent survey of manufacturing firms in Bangladesh to obtain consistent firm time-varying TFP measures for the period 1999-2003 following Olley and Pakes (1996) and empirically investigate the determinants of firm TFP levels.

Our main findings are as follows. First, we find an inefficient allocation of resources within the pharmaceuticals, leather/footwear, and textiles industries during the sample period, as less productive firms have a higher share of total industry output. Second, our econometric results identify important determinants of firm TFP, controlling for industry, location, and year fixed effects. Smaller firms are significantly more productive than firms in the largest size category (more than 500 workers). Firm age and TFP exhibit an inverse-U shaped relationship. Firms with a more educated or more skilled workforce and more educated or more experienced managers are more productive. Firm TFP benefits from the integration into world markets: foreign-owned firms and exporters have significantly higher TFP. Firms with staff engaged in R\&D activities and firms with quality certifications have higher TFP. However, firms with more advanced technologies improve TFP only in the presence of significant absorptive capacity. While firms with an overdraft facility have significantly higher TFP, firms with access to a bank loan have significantly lower TFP. Power supply problems have a significant negative effect on firm TFP. The presence of crime in industries and locations hurts firm TFP.

Our findings point out to several key areas of policy relevance in which improvements are likely to bring benefits for firm TFP in Bangladesh. The acceleration of infrastructure development seems to be a crucial business environment reform to

\footnotetext{
${ }^{50}$ This argument assumes that more productive firms can be identified by government officials.
} 
pursue. Policies promoting human capital formation at various levels can have very important benefits for firm TFP. Progress in international integration of firms into world markets either through their participation in export markets or by the attraction of foreign-capital is also likely to have large payoffs in terms of TFP. However, note that our framework does not allow one to conclude which policy would be more costeffective. Future work in that direction would be fruitful.

Finally, we should mention that while this paper conveys valuable information on the dynamics of firms in five manufacturing industries in Bangladesh, it is based on a survey that covers relatively large firms. Pursuing a similar type of analysis using manufacturing census data - collected in a comprehensive and regular fashion - will be even more valuable. Such data collection efforts can have large payoffs for policy-makers as they enable them to closely follow the trends in manufacturing firms' performance and generate appropriate policy responses when necessary. 


\section{References}

Aitken, B. and A. Harrison (1999). "Do Domestic Firms Benefit from Direct Foreign Investment? Evidence from Venezuela,” American Economic Review 89, 183207.

Arnold, J. and B. Javorcik (2005). "Gifted Kids or Pushy Parents? Foreign Acquisitions and Plant Productivity in Indonesia,” World Bank Policy Research Working Paper 3597.

Aw, B., Roberts, M. and T. Winston (2005). “The Complementary Role of Exports and R\&D Investments as Sources of Productivity Growth,” NBER Working Paper 11774.

Barro, R. and J. Lee (2000). "International Data on Educational Attainment Updates and Implications,” NBER Working Paper 7911.

Bartelsman, E. and M. Doms (2000). “Understanding Productivity: Lessons from Longitudinal Microdata,” Journal of Economic Literature 38, 569-594.

Beck, T., Demirgüç-Kunt, A., and V. Maksimovic (2005). "Financial and Legal Constraints to Firm Growth: Does Firm Size Matter?,” Journal of Finance 60, 137-177.

Blalock, G. and P. Gertler (2004). "Learning from Exporting Revisited in a Less Developed Country Setting,” Journal of Development Economics 75, 397-416.

Burki, A. and D. Terrell (1998) "Measuring Production Efficiency of Small Firms in Pakistan,” World Development 26(1), 155-169.

Caves, R. (1998). "Industrial Organization and New Findings on the Turnover and Mobility of Firms,” Journal of Economic Literature 36, 1947-1982.

Cohen, W., and Levinthal, D. (1989). "Innovation and Learning: The Two Faces of R\&D,” Economic Journal 99(397), pp. 569-596.

Dollar, D., Hallward-Driemeier, M. and T. Mengistae (2005). "Investment Climate and Firm Performance in Developing Economies," Economic Development and Cultural Change 54, 1-31.

Easterly, W. and R. Levine (2001). "It's Not Factor Accumulation: Stylized Facts and Growth Models,” World Bank Economic Review 15(2) 177-219.

Fernandes, A. and A. Isgut (2006). "Learning-by-Exporting Effects: Are They for Real?,," mimeo, the World Bank.

Fisman, R. and J. Svensson (2006) "Are Corruption and Taxation Really Harmful to Growth?: Firm Level Evidence,” Journal of Development Economics forthcoming.

Griffith, R., Redding, S., and J. Van Reenen (2004). “Mapping the Two Faces of R\&D: Productivity Growth in a Panel of OECD Industries," Review of Economics and Statistics 86(4), 883-895.

Griliches, Z. (1998), R\&D and Productivity: The Econometric Evidence Chicago: University of Chicago Press.

Hallward-Driemeier, M., Wallsten, S., and C. Xu (2003) "The Investment Climate and the Firm : Firm-Level Evidence from China,” World Bank World Bank Working Paper 3003. 
Javorcik, B. (2004). "Does Foreign Direct Investment Increase the Productivity of Domestic Firms? In Search of Spillovers through Backward Linkages,” American Economic Review 94, 605-627.

Jovanovic, B. (1982). "Selection and the Evolution of Industry," Econometrica 50, 649670.

Jensen, J., McGuckin, R., and J. Stiroh (2001). "The Impact of Vintage and Survival on Productivity: Evidence from Cohorts of U.S. Manufacturing Plants," Review of Economics and Statistics 83(2), 323-332.

Katayama, H., Lu, S., and J. Tybout (2003). "Why plant-level productivity studies are often misleading, and an alternative approach to inference," NBER Working Paper 9617.

Kee, H., (2006). “Foreign Investment and Domestic Productivity,” mimeo, The World Bank.

Kraay, A. (1999). "Exportations et Performances Economiques: Etude d'un Panel d'Entreprises Chinoises," Revue d'Economie du Developpement 0, 183-207.

Lall, S. and G. Rodrigo (2001). "Perspectives on the Sources of Heterogeneity in Indian Industry,” World Development 29(12), 2127-2143.

Levinsohn, J. and A. Petrin (2003). "Estimating Production Functions Using Inputs to Control for Unobservables," Review of Economic Studies 70, 317-341.

Mahajan, S. (2005). "Sources of Productivity Growth in Bangladesh," mimeo, The World Bank.

Olley, G. and A. Pakes (1996). "The Dynamics of Productivity in the Telecommunications Equipment Industry,” Econometrica 64, 1263-1297.

Roberts, M. and J. Tybout (1997). "The Decision to Export in Colombia: An Empirical Model of Entry with Sunk Costs,” American Economic Review 87, 545-564.

Sakellaris, P. (2004). "Patterns of Plant Adjustment," Journal of Monetary Economics 51, 425-450.

Svensson, J. (2003) "Who Must Pay Bribes and How Much?: Evidence from a CrossSection of Firms," Quarterly Journal of Economics 118(1), 207-230.

Tan, H. and G. Lopez-Acevedo (2002). "Mexico: In-Firm Training for the Knowledge Economy” World Bank Policy Research Working Paper 2957.

Tybout, J., (2000). "Manufacturing Firms in Developing Countries: How Well Do They Do, and Why?” Journal of Economic Literature 38, 11--44.

Van Biesebroeck, J. (2005). "Firm Size Matters: Growth and Productivity Growth in African Manufacturing," Economic Development and Cultural Change 53, 545583.

Wagner, J. (2006). "Exports and Productivity: A Survey of Evidence from Firm Level Data," World Economy forthcoming.

Westphal, L. (2002). "Technology Strategies for Economic Development in a Fast Changing Global Economy," Economics of Innovation and New Technology, 11, 275-320.

World Bank (2005). End of MFA Quotas: Key Issues and Strategic Options for Bangladesh Readymade Garment Industry. 
Figure 1: Industry Average TFP and Labor Productivity
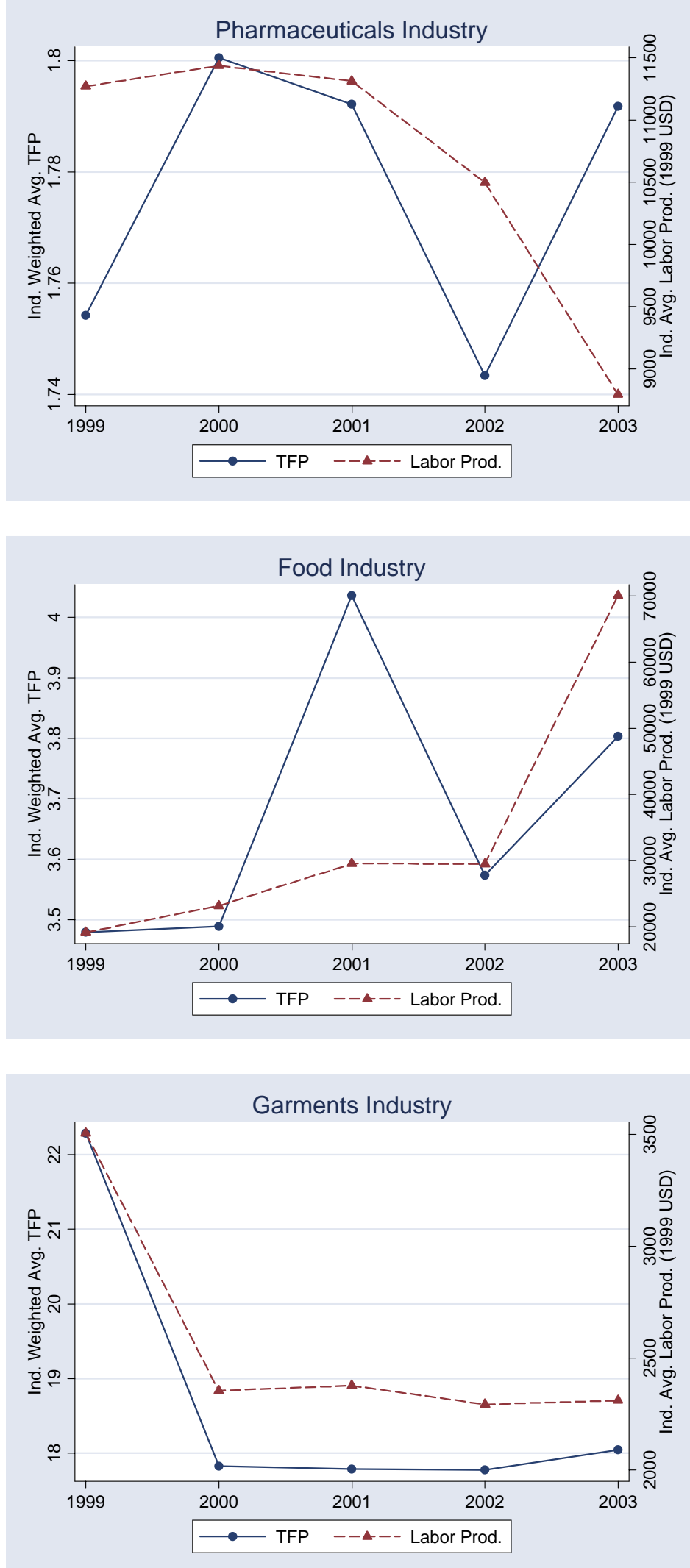
Figure 1 (continued)
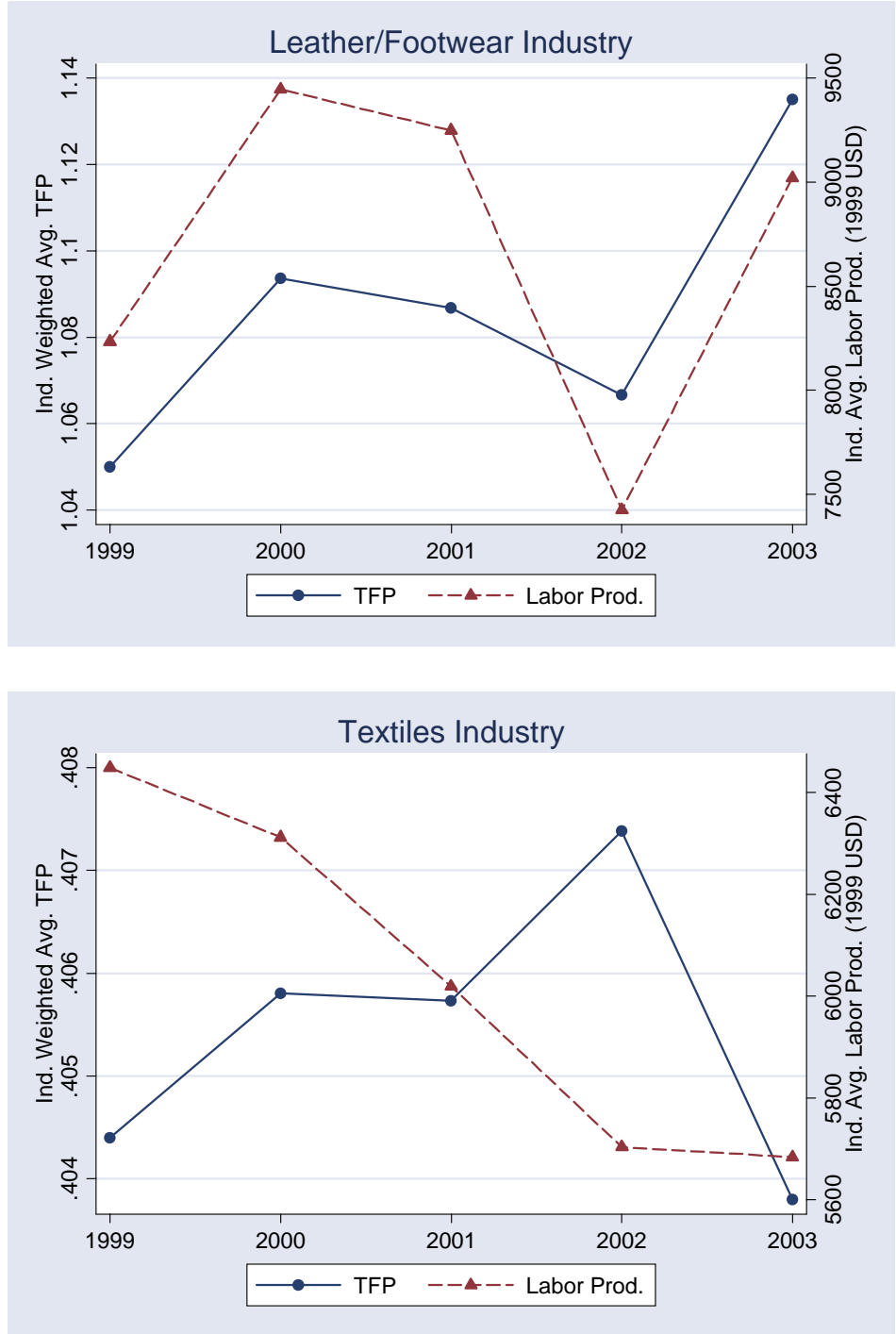
Figure 2: Median Firm TFP Growth, Output and Input Growth
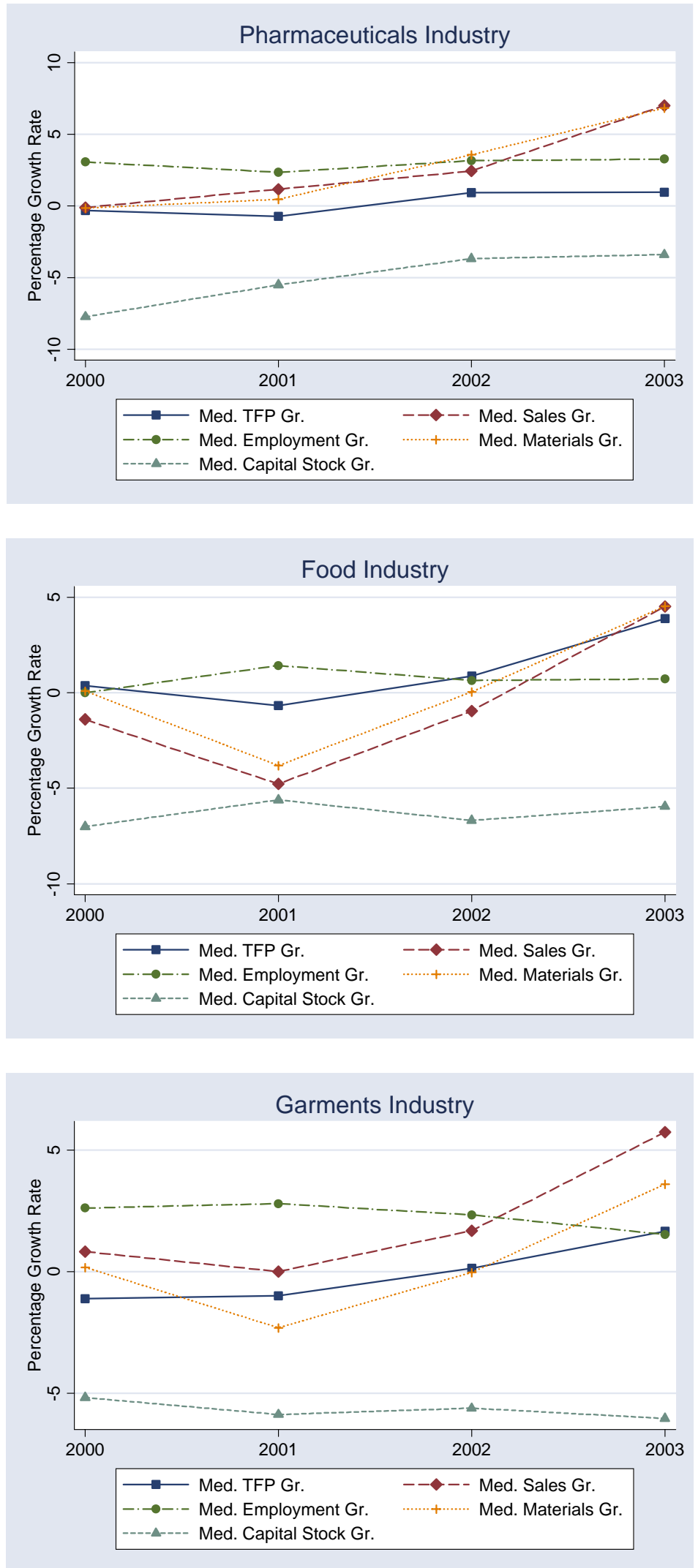


\section{Figure 2 (continued)}
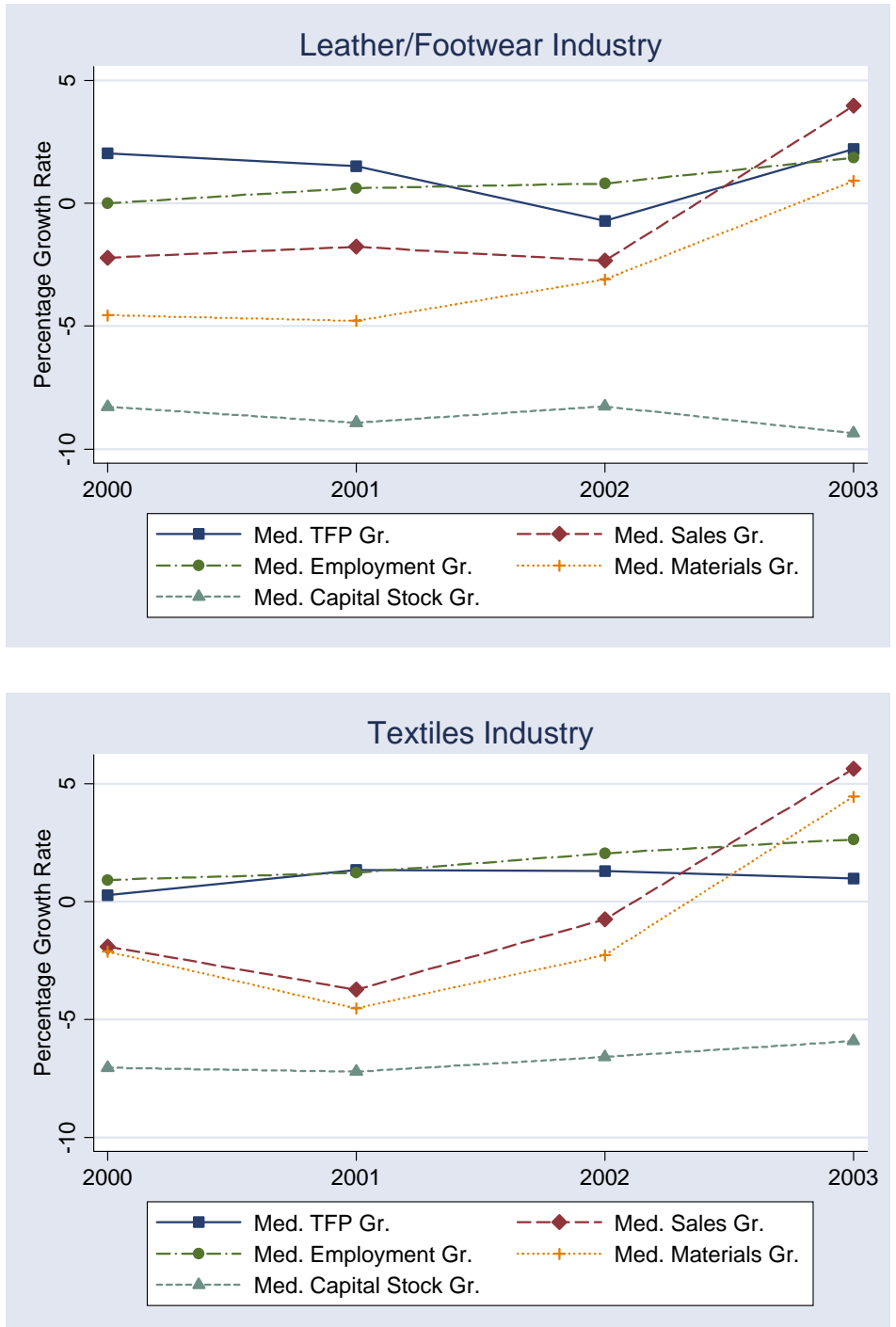

Note: For each industry and year, the figure shows the median firm growth rates of TFP, output, and inputs. 
Figure 3: Decomposition of Industry TFP
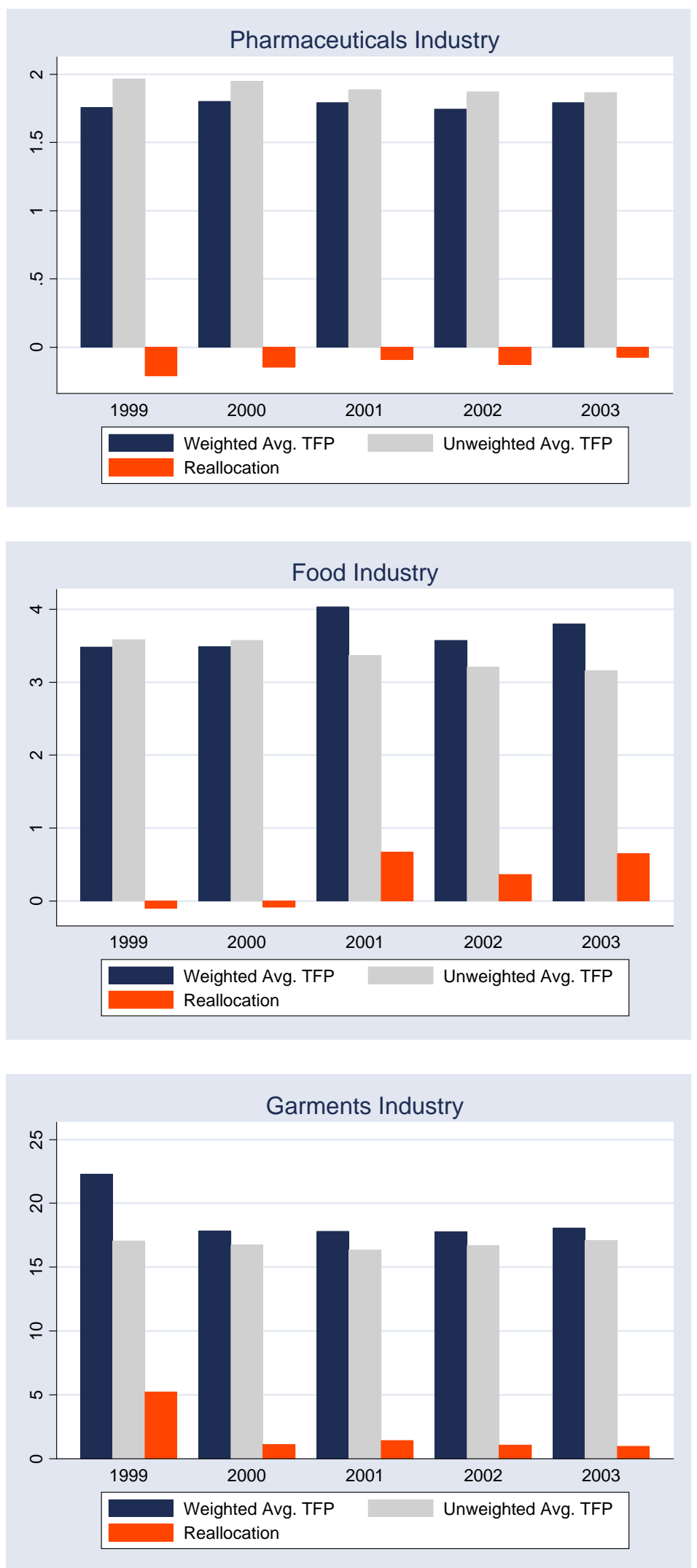
Figure 3 (continued)
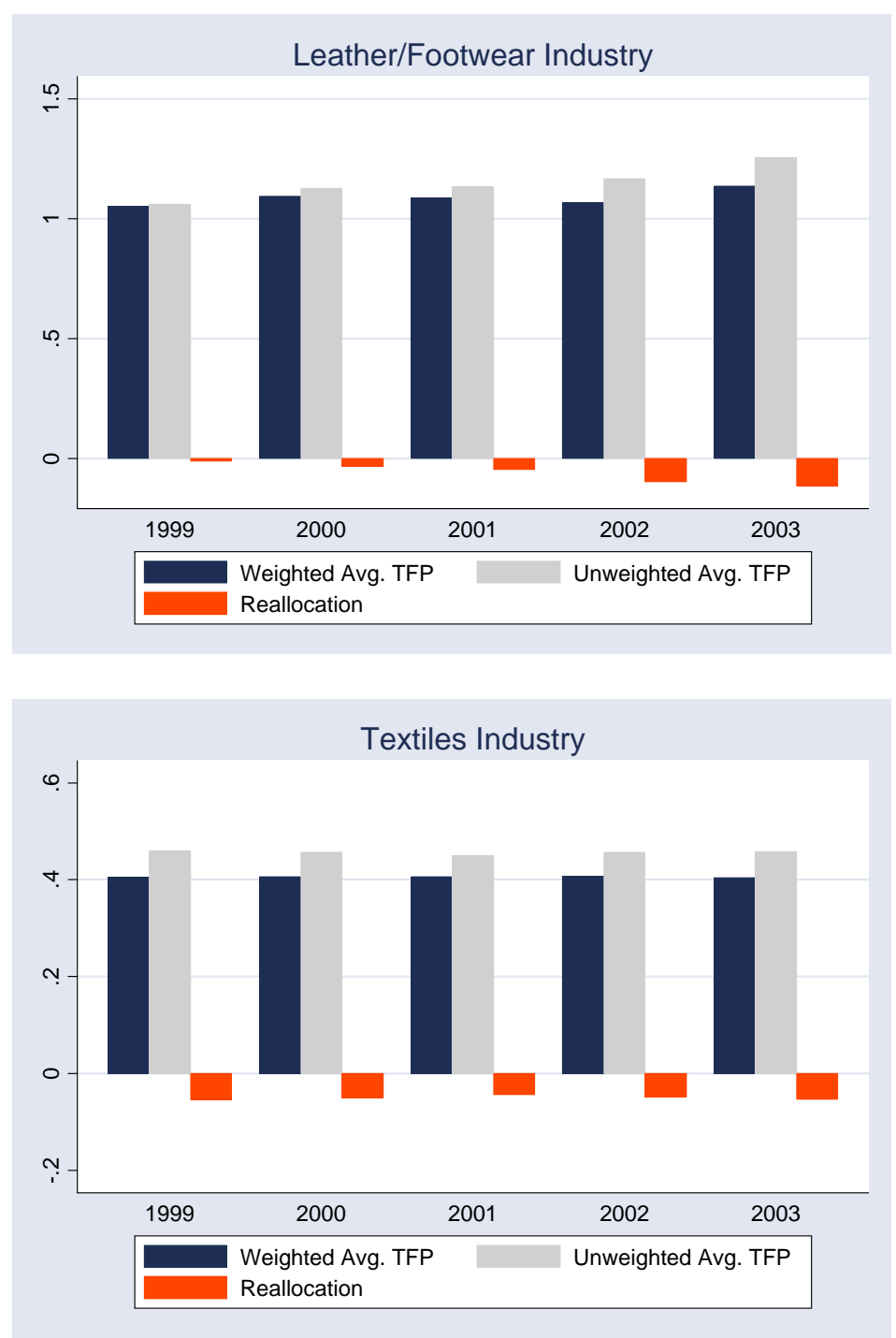
Table 1: Production Function Estimates

\begin{tabular}{lccc|ccc|cccc}
\hline Industry & \multicolumn{3}{c|}{ Pharmaceuticals } & \multicolumn{3}{c|}{ Food } & \multicolumn{3}{c}{ Ready-Made Garments } \\
\hline \multicolumn{1}{c}{ OLS } & FE & OP & OLS & FE & OP & OLS & FE & OP \\
\hline Labor & $0.249^{* * *}$ & $0.350^{* * *}$ & $0.273^{* * *}$ & $0.284^{* * *}$ & $0.306^{* * *}$ & $0.185^{* * *}$ & $0.281^{* * *}$ & $0.332^{* * *}$ & $0.321^{* * *}$ \\
& $(0.032)$ & $(0.043)$ & $(0.032)$ & $(0.040)$ & $(0.064)$ & $(0.047)$ & $(0.031)$ & $(0.033)$ & $(0.035)$ \\
Materials & $0.810^{* * *}$ & $0.703^{* * *}$ & $0.795^{* * *}$ & $0.595^{* * *}$ & $0.627^{* * *}$ & $0.575^{* * *}$ & $0.717^{* * *}$ & $0.706^{* * *}$ & $0.677^{* * *}$ \\
& $(0.021)$ & $(0.028)$ & $(0.023)$ & $(0.030)$ & $(0.019)$ & $(0.030)$ & $(0.027)$ & $(0.016)$ & $(0.028)$ \\
Capital & 0.026 & -0.013 & 0.098 & $0.177^{* * *}$ & $0.122^{* * *}$ & $0.335^{* * *}$ & 0.003 & -0.049 & 0.019 \\
& $(0.010)$ & $(0.031)$ & $(0.064)$ & $(0.031)$ & $(0.052)$ & $(0.126)$ & $(0.006)$ & $(0.024)$ & $(0.017)$ \\
Year Effects & Yes & Yes & Yes & Yes & Yes & Yes & Yes & Yes & Yes \\
N. Observations & 236 & 236 & 203 & 382 & 382 & 312 & 1176 & 1176 & 858 \\
\hline
\end{tabular}

\begin{tabular}{lccc|ccc}
\hline Industry & \multicolumn{3}{c|}{ Leather } & \multicolumn{3}{c}{ Textiles } \\
\hline Labor & OLS & FE & OP & OLS & FE & OP \\
& $0.100^{* * *}$ & 0.126 & $0.110^{* * *}$ & $0.125^{* * *}$ & $0.127^{* * *}$ & $0.061^{* * *}$ \\
Materials & $(0.017)$ & $(0.118)$ & $(0.021)$ & $(0.011)$ & $(0.029)$ & $(0.009)$ \\
& $0.917^{* * *}$ & $0.917^{* * *}$ & $0.882^{* * *}$ & $0.871^{* * *}$ & $0.843^{* * *}$ & $0.915^{* * *}$ \\
Capital & $(0.016)$ & $(0.039)$ & $(0.030)$ & $(0.010)$ & $(0.022)$ & $(0.010)$ \\
& -0.009 & -0.168 & 0.036 & $0.015^{* * *}$ & 0.057 & $0.147^{* * *}$ \\
& $(0.022)$ & $(0.203)$ & $(0.027)$ & $(0.007)$ & $(0.035)$ & $(0.046)$ \\
Year Effects & & & & & & \\
& Yes & Yes & Yes & Yes & Yes & Yes \\
N. Observations & 122 & 122 & 108 & 574 & 574 & 413 \\
\hline
\end{tabular}

Notes: Robust standard errors in parentheses in the columns with OLS estimates. ***, **, and * represent significance at $1 \%, 5 \%$, and $10 \%$ confidence levels, respectively. FE stands for fixed effects estimates and OP stands for Olley and Pakes (1996) estimates.

Table 2: Average Growth in Industry Labor Productivity and TFP

\begin{tabular}{lcc}
\hline Industry & $\begin{array}{c}\text { Industry Avg. } \\
\text { Labor } \\
\text { Productivity }\end{array}$ & $\begin{array}{c}\text { Industry Weighted } \\
\text { Avg. TFP }\end{array}$ \\
\hline Average Growth in 1999-2003: & & \\
Pharmaceuticals & $-3.02 \%$ & $0.56 \%$ \\
Food & $11.17 \%$ & $2.73 \%$ \\
Ready-Made Garments & $-1.81 \%$ & $-4.69 \%$ \\
Leather & $11.31 \%$ & $2.02 \%$ \\
Textiles & $-1.94 \%$ & $-0.04 \%$ \\
\hline
\end{tabular}

Note: Weighted averages are calculated with firms' shares in total sales for the industry and year as weights. 
Table 3: Average and Median Firm TFP Growth and Labor Productivity Growth

\begin{tabular}{|c|c|c|c|c|c|}
\hline \multirow[t]{2}{*}{ Industry } & \multirow[t]{2}{*}{ Year } & $\begin{array}{l}\text { Firm-Level Labor } \\
\text { Product. Growth }\end{array}$ & $\begin{array}{l}\text { Firm-Level Labor } \\
\text { Product. Growth }\end{array}$ & $\begin{array}{l}\text { Firm-Level } \\
\text { TFP Growth }\end{array}$ & $\begin{array}{l}\text { Firm-Level } \\
\text { TFP Growth }\end{array}$ \\
\hline & & Average & Median & Average & Median \\
\hline \multirow[t]{4}{*}{ Pharmaceuticals } & $1999-2000$ & $-0.73 \%$ & $-1.84 \%$ & $-0.55 \%$ & $-0.33 \%$ \\
\hline & $2000-2001$ & $-3.34 \%$ & $-3.38 \%$ & $-1.59 \%$ & $-0.74 \%$ \\
\hline & 2001-2002 & $2.29 \%$ & $-0.54 \%$ & $0.08 \%$ & $0.92 \%$ \\
\hline & $2002-2003$ & $2.37 \%$ & $1.43 \%$ & $-0.25 \%$ & $0.97 \%$ \\
\hline \multirow[t]{4}{*}{ Food } & 1999-2000 & $20.22 \%$ & $-7.00 \%$ & $-0.10 \%$ & - \\
\hline & $2000-2001$ & $-5.61 \%$ & $-5.68 \%$ & $-0.20 \%$ & $-0.68 \%$ \\
\hline & 2001-2002 & $-0.56 \%$ & $-2.63 \%$ & $-1.16 \%$ & $0.89 \%$ \\
\hline & $2002-2003$ & $3.10 \%$ & $3.23 \%$ & $3.12 \%$ & $3.89 \%$ \\
\hline \multirow[t]{4}{*}{ Ready-Made Garments } & 1999-2000 & 3.18\% & $-2.86 \%$ & $-0.04 \%$ & $-1.11 \%$ \\
\hline & $2000-2001$ & $0.06 \%$ & $-2.86 \%$ & $-0.77 \%$ & $-1.00 \%$ \\
\hline & 2001-2002 & $6.45 \%$ & $-0.05 \%$ & $2.61 \%$ & $0.13 \%$ \\
\hline & $2002-2003$ & $17.78 \%$ & $4.21 \%$ & $5.24 \%$ & $1.67 \%$ \\
\hline \multirow[t]{4}{*}{ Leather } & 1999-2000 & $15.94 \%$ & $0.45 \%$ & $5.82 \%$ & $2.03 \%$ \\
\hline & $2000-2001$ & $14.98 \%$ & $5.61 \%$ & $2.71 \%$ & $1.51 \%$ \\
\hline & 2001-2002 & $-3.29 \%$ & $-5.13 \%$ & $2.21 \%$ & $-0.72 \%$ \\
\hline & $2002-2003$ & $34.46 \%$ & $9.51 \%$ & $6.40 \%$ & $2.20 \%$ \\
\hline \multirow[t]{4}{*}{ Textiles } & 1999-2000 & $-0.86 \%$ & $-4.81 \%$ & $1.22 \%$ & $0.26 \%$ \\
\hline & $2000-2001$ & $7.62 \%$ & $-1.98 \%$ & $2.07 \%$ & $1.34 \%$ \\
\hline & 2001-2002 & $4.68 \%$ & $-0.20 \%$ & $2.17 \%$ & $1.28 \%$ \\
\hline & $2002-2003$ & $6.07 \%$ & $2.51 \%$ & $1.80 \%$ & $0.97 \%$ \\
\hline
\end{tabular}

Note: The cells in the table show the average and the median of firm growth rates in labor productivity and of firm growth rates in TFP. 
Table 4: Determinants of Firm TFP

\begin{tabular}{|c|c|c|c|c|c|c|}
\hline & \multicolumn{6}{|c|}{ Dependent Variable is TFP } \\
\hline & (1) & (2) & (3) & (4) & (5) & (6) \\
\hline Very Large Size Dummy (150 to 500 Workers) & $\begin{array}{l}0.035^{\star \star \star} \\
(0.013)\end{array}$ & $\begin{array}{l}0.034^{\star \star} \\
(0.013)\end{array}$ & $\begin{array}{l}0.045^{\star \star \star} \\
(0.013)\end{array}$ & $\begin{array}{l}0.031^{\star \star} \\
(0.013)\end{array}$ & $\begin{array}{l}0.030^{\star \star} \\
(0.013)\end{array}$ & $\begin{array}{l}0.041^{\star \star \star} \\
(0.013)\end{array}$ \\
\hline Relatively Large Size Dummy (50 to 150 Workers) & $\begin{array}{l}0.232^{\star * *} \\
(0.028)\end{array}$ & $\begin{array}{c}0.223^{* * *} \\
(0.028)\end{array}$ & $\begin{array}{c}0.239 * \star * \\
(0.028)\end{array}$ & $\begin{array}{c}0.219 * * * \\
(0.028)\end{array}$ & $\begin{array}{l}0.210^{* * *} \\
(0.028)\end{array}$ & $\begin{array}{l}0.226^{\star \star \star *} \\
(0.028)\end{array}$ \\
\hline Medium Size Dummy (10 to 50 Workers) & $\begin{array}{c}0.310^{\star \star \star} \\
(0.044)\end{array}$ & $\begin{array}{l}0.305^{\star \star *} \\
(0.044)\end{array}$ & $\begin{array}{l}0.314^{\star \star * *} \\
(0.044)\end{array}$ & $\begin{array}{l}0.303^{\star * *} \\
(0.044)\end{array}$ & $\begin{array}{c}0.298^{\star \star *} \\
(0.044)\end{array}$ & $\begin{array}{c}0.306^{\star \star \star} \\
(0.044)\end{array}$ \\
\hline Small Size Dummy (Less than 10 Workers) & $\begin{array}{l}0.256^{\star \star \star} \\
(0.053)\end{array}$ & $\begin{array}{c}0.252^{\star \star \star} \\
(0.052)\end{array}$ & $\begin{array}{l}0.229 \star \star \star \\
(0.051)\end{array}$ & $\begin{array}{c}0.174^{\star \star \star} \\
(0.055)\end{array}$ & $\begin{array}{c}0.169 \star \star \star \\
(0.055)\end{array}$ & $\begin{array}{c}0.146^{\star \star \star} \\
(0.055)\end{array}$ \\
\hline Dummy for Firms Aged 5 to 10 Years Old & $\begin{array}{l}0.098^{\star * *} \\
(0.024)\end{array}$ & $\begin{array}{c}0.093^{* * *} \\
(0.024)\end{array}$ & $\begin{array}{c}0.073^{\star \star \star} \\
(0.025)\end{array}$ & $\begin{array}{c}0.101^{\star * \star} \\
(0.024)\end{array}$ & $\begin{array}{c}0.096 * \star \star \\
(0.024)\end{array}$ & $\begin{array}{c}0.075^{\star \star \star} \\
(0.025)\end{array}$ \\
\hline Dummy for Firms Aged 10 to 20 Years Old & $\begin{array}{c}0.145^{\star \star \star} \\
(0.025)\end{array}$ & $\begin{array}{l}0.138^{\star * \star} \\
(0.026)\end{array}$ & $\begin{array}{c}0.087^{\star * *} \\
(0.029)\end{array}$ & $\begin{array}{l}0.143^{\star \star *} \\
(0.026)\end{array}$ & $\begin{array}{l}0.136 * \star * \\
(0.026)\end{array}$ & $\begin{array}{c}0.083^{\star \star \star} \\
(0.029)\end{array}$ \\
\hline Dummy for Firms Aged 20 to 40 Years Old & $\begin{array}{l}0.144^{\star \star \star} \\
(0.031)\end{array}$ & $\begin{array}{c}0.146^{\star \star \star} \\
(0.032)\end{array}$ & $\begin{array}{c}0.066^{\star} \\
(0.034)\end{array}$ & $\begin{array}{l}0.141^{\star * *} \\
(0.031)\end{array}$ & $\begin{array}{c}0.143^{\star \star \star} \\
(0.031)\end{array}$ & $\begin{array}{l}0.062^{\star} \\
(0.034)\end{array}$ \\
\hline Dummy for Firms Aged More than 40 Years Old & $\begin{array}{c}0.039 \\
(0.035)\end{array}$ & $\begin{array}{c}0.046 \\
(0.035)\end{array}$ & $\begin{array}{l}-0.016 \\
(0.036)\end{array}$ & $\begin{array}{c}0.035 \\
(0.035)\end{array}$ & $\begin{array}{c}0.043 \\
(0.035)\end{array}$ & $\begin{array}{l}-0.021 \\
(0.036)\end{array}$ \\
\hline Skilled Workers Share & $\begin{array}{c}0.115^{\star \star \star} \\
(0.042)\end{array}$ & $\begin{array}{c}0.123^{\star \star *} \\
(0.042)\end{array}$ & $\begin{array}{l}0.104^{* *} \\
(0.041)\end{array}$ & $\begin{array}{c}0.110^{\star * *} \\
(0.041)\end{array}$ & $\begin{array}{c}0.118^{\star \star \star} \\
(0.041)\end{array}$ & $\begin{array}{l}0.099 * * \\
(0.041)\end{array}$ \\
\hline Dummy for Managers with Post-Graduate Education & $\begin{array}{c}0.024 \\
(0.015)\end{array}$ & $\begin{array}{c}0.023 \\
(0.015)\end{array}$ & $\begin{array}{l}0.032^{\star *} \\
(0.015)\end{array}$ & $\begin{array}{c}0.027^{*} \\
(0.015)\end{array}$ & $\begin{array}{c}0.027^{*} \\
(0.015)\end{array}$ & $\begin{array}{l}0.036^{\star *} \\
(0.015)\end{array}$ \\
\hline Manager Years of Experience (log) & $\begin{array}{c}0.015^{\star} \\
(0.009)\end{array}$ & $\begin{array}{c}0.015^{\star} \\
(0.008)\end{array}$ & $\begin{array}{c}0.012 \\
(0.008)\end{array}$ & $\begin{array}{c}0.015^{\star} \\
(0.009)\end{array}$ & $\begin{array}{l}0.016^{*} \\
(0.008)\end{array}$ & $\begin{array}{c}0.013 \\
(0.008)\end{array}$ \\
\hline Foreign-Owned Dummy & $\begin{array}{l}0.083^{\star} \\
(0.048)\end{array}$ & $\begin{array}{l}0.085^{\star} \\
(0.048)\end{array}$ & $\begin{array}{c}0.071 \\
(0.048)\end{array}$ & $\begin{array}{l}0.087^{\star} \\
(0.047)\end{array}$ & $\begin{array}{l}0.089^{\star} \\
(0.047)\end{array}$ & $\begin{array}{c}0.076 \\
(0.047)\end{array}$ \\
\hline Exporters Dummy & $\begin{array}{c}0.095^{\star \star \star} \\
(0.022)\end{array}$ & & & $\begin{array}{c}0.098 * * * \\
(0.022)\end{array}$ & & \\
\hline Majority Exporters Dummy & & $\begin{array}{c}0.094^{\star \star \star *} \\
(0.024)\end{array}$ & & & $\begin{array}{c}0.097^{\star \star \star} \\
(0.024)\end{array}$ & \\
\hline Years of Export Experience (log) & & & $\begin{array}{l}0.047^{* * *} \\
(0.009)\end{array}$ & & & $\begin{array}{c}0.048^{\star \star *} \\
(0.009)\end{array}$ \\
\hline Dummy for R\&D Staff & $\begin{array}{l}0.033^{\star \star} \\
(0.016)\end{array}$ & $\begin{array}{l}0.034^{\star \star} \\
(0.016)\end{array}$ & $\begin{array}{l}0.039 * * \\
(0.017)\end{array}$ & $\begin{array}{c}0.031^{*} \\
(0.016)\end{array}$ & $\begin{array}{c}0.031 * \\
(0.016)\end{array}$ & $\begin{array}{l}0.036^{\star *} \\
(0.017)\end{array}$ \\
\hline Quality Certification Dummy & $\begin{array}{c}0.055^{\star \star \star} \\
(0.016)\end{array}$ & $\begin{array}{c}0.059 * \star * \\
(0.016)\end{array}$ & $\begin{array}{c}0.054^{\star \star *} \\
(0.016)\end{array}$ & $\begin{array}{c}0.057^{\star \star *} \\
(0.016)\end{array}$ & $\begin{array}{c}0.061^{\star \star *} \\
(0.016)\end{array}$ & $\begin{array}{c}0.057^{\star \star \star} \\
(0.016)\end{array}$ \\
\hline Perc. of Machinery Less than 5 Years Old & $\begin{array}{l}-0.080^{\star \star *} \\
(0.025)\end{array}$ & $\begin{array}{c}-0.085^{\star \star *} \\
(0.026)\end{array}$ & $\begin{array}{l}-0.064^{\star \star} \\
(0.025)\end{array}$ & $\begin{array}{l}-0.087^{\star \star \star *} \\
(0.025)\end{array}$ & $\begin{array}{c}-0.092^{\star \star \star} \\
(0.026)\end{array}$ & $\begin{array}{l}-0.071^{\star \star \star} \\
(0.025)\end{array}$ \\
\hline Perc. of Computerized Machinery & $\begin{array}{c}-0.128^{\star \star \star} \\
(0.030)\end{array}$ & $\begin{array}{c}-0.1166^{\star \star \star} \\
(0.030)\end{array}$ & $\begin{array}{c}-0.133^{\star \star \star} \\
(0.030)\end{array}$ & $\begin{array}{c}-0.121^{\star \star \star} \\
(0.030)\end{array}$ & $\begin{array}{c}-0.108^{\star \star *} \\
(0.030)\end{array}$ & $\begin{array}{c}-0.125^{\star \star \star} \\
(0.030)\end{array}$ \\
\hline Overdraft Dummy & $\begin{array}{c}0.027^{\star} \\
(0.015)\end{array}$ & $\begin{array}{c}0.028^{*} \\
(0.015)\end{array}$ & $\begin{array}{l}0.031^{* *} \\
(0.015)\end{array}$ & $\begin{array}{c}0.028^{*} \\
(0.015)\end{array}$ & $\begin{array}{l}0.030 * * \\
(0.015)\end{array}$ & $\begin{array}{l}0.033^{\star *} \\
(0.015)\end{array}$ \\
\hline Loan Dummy & $\begin{array}{c}-0.060^{\star \star \star} \\
(0.015)\end{array}$ & $\begin{array}{c}-0.056^{\star \star \star \star} \\
(0.015)\end{array}$ & $\begin{array}{c}-0.063^{\star \star \star} \\
(0.015)\end{array}$ & $\begin{array}{c}-0.057^{\star \star \star} \\
(0.014)\end{array}$ & $\begin{array}{c}-0.053^{\star \star \star} \\
(0.014)\end{array}$ & $\begin{array}{c}-0.060^{\star \star \star *} \\
(0.014)\end{array}$ \\
\hline Days to Clear Customs for Imports (log) & $\begin{array}{c}0.002 \\
(0.041)\end{array}$ & $\begin{array}{c}0.009 \\
(0.041)\end{array}$ & $\begin{array}{l}-0.002 \\
(0.040)\end{array}$ & $\begin{array}{c}0.005 \\
(0.041)\end{array}$ & $\begin{array}{c}0.012 \\
(0.040)\end{array}$ & $\begin{array}{c}0.001 \\
(0.040)\end{array}$ \\
\hline Number of Power Interruptions (log) & $\begin{array}{c}-0.077^{\star \star} \\
(0.035)\end{array}$ & $\begin{array}{c}-0.083^{\star \star} \\
(0.035)\end{array}$ & $\begin{array}{c}-0.086^{\star \star} \\
(0.034)\end{array}$ & $\begin{array}{l}-0.060^{*} \\
(0.035)\end{array}$ & $\begin{array}{l}-0.066^{\star} \\
(0.036)\end{array}$ & $\begin{array}{l}-0.068^{\star *} \\
(0.034)\end{array}$ \\
\hline Number of Power Interruptions (log)* Generator & & & & $\begin{array}{c}-0.012^{\star \star \star} \\
(0.004)\end{array}$ & $\begin{array}{c}-0.012^{\star \star \star} \\
(0.004)\end{array}$ & $\begin{array}{c}-0.012^{\star \star \star} \\
(0.004)\end{array}$ \\
\hline Perc. Manag. Time Spent Dealing with Regulation & $\begin{array}{l}0.177^{\star *} \\
(0.084)\end{array}$ & $\begin{array}{l}0.169 * * \\
(0.083)\end{array}$ & $\begin{array}{c}0.143^{*} \\
(0.078)\end{array}$ & $\begin{array}{l}0.165^{\star *} \\
(0.081)\end{array}$ & $\begin{array}{l}0.157^{\star *} \\
(0.080)\end{array}$ & $\begin{array}{l}0.132^{\star} \\
(0.076)\end{array}$ \\
\hline Avg. Perc. of Sales Paid in Bribes to Get Things Done & $\begin{array}{l}0.033^{\star \star} \\
(0.015)\end{array}$ & $\begin{array}{l}0.029 * \\
(0.015)\end{array}$ & $\begin{array}{l}0.036^{\star \star} \\
(0.015)\end{array}$ & $\begin{array}{l}0.033^{\star \star} \\
(0.015)\end{array}$ & $\begin{array}{l}0.029 * \star \\
(0.014)\end{array}$ & $\begin{array}{l}0.036 \star \star \\
(0.014)\end{array}$ \\
\hline Protection Payments as Perc. Sales & $\begin{array}{c}-54.611^{\star \star \star} \\
(11.968)\end{array}$ & $\begin{array}{c}-54.410^{\star \star \star} \\
(11.932)\end{array}$ & $\begin{array}{c}-54.103^{\star \star \star} \\
(11.726)\end{array}$ & $\begin{array}{c}-56.144^{\star \star \star} \\
(11.046)\end{array}$ & $\begin{array}{c}-55.940 * \star \star \\
(11.027)\end{array}$ & $\begin{array}{c}-55.556^{\star \star \star} \\
(10.813)\end{array}$ \\
\hline Industry Fixed Effects & Yes & Yes & Yes & Yes & Yes & Yes \\
\hline $\begin{array}{l}\text { Year Fixed Effects } \\
\text { Location Fixed Effects }\end{array}$ & $\begin{array}{l}\text { Yes } \\
\text { Yes }\end{array}$ & $\begin{array}{l}\text { Yes } \\
\text { Yes }\end{array}$ & $\begin{array}{l}\text { Yes } \\
\text { Yes }\end{array}$ & $\begin{array}{l}\text { Yes } \\
\text { Yes }\end{array}$ & $\begin{array}{l}\text { Yes } \\
\text { Yes }\end{array}$ & $\begin{array}{l}\text { Yes } \\
\text { Yes }\end{array}$ \\
\hline $\begin{array}{l}\text { Number of Observations } \\
\text { R-squared }\end{array}$ & $\begin{array}{l}2231 \\
0.96\end{array}$ & $\begin{array}{l}2231 \\
0.96\end{array}$ & $\begin{array}{l}2217 \\
0.96\end{array}$ & $\begin{array}{l}2226 \\
0.96\end{array}$ & $\begin{array}{l}2226 \\
0.96\end{array}$ & $\begin{array}{l}2212 \\
0.96\end{array}$ \\
\hline
\end{tabular}

Notes: OLS estimation is used. Robust standard errors in parentheses. ***, **, and * indicate significance at $1 \%, 5 \%$, and $10 \%$ confidence levels, respectively. The omitted size category is extremely large firms (more than 500 workers) and the omitted age category is firms less than 5 years old. 
Table 5: Determinants of Firm TFP - Interactions of Technology and R\&D

\begin{tabular}{|c|c|c|c|c|c|c|}
\hline & \multicolumn{6}{|c|}{ Dependent Variable is TFP } \\
\hline & $(1)$ & $(2)$ & (3) & (4) & (5) & (6) \\
\hline Very Large Dummy (150 to 500 Workers) & $\begin{array}{c}0.035^{\star \star \star} \\
(0.013)\end{array}$ & $\begin{array}{c}0.035^{\star \star \star} \\
(0.013)\end{array}$ & $\begin{array}{c}0.045^{\star \star \star} \\
(0.013)\end{array}$ & $\begin{array}{c}0.037^{\star \star \star} \\
(0.013)\end{array}$ & $\begin{array}{c}0.037^{\star \star \star} \\
(0.013)\end{array}$ & $\begin{array}{c}0.046^{\star \star \star} \\
(0.013)\end{array}$ \\
\hline Relatively Large Dummy (50 to 150 Workers) & $\begin{array}{c}0.230^{\star \star \star} \\
(0.028)\end{array}$ & $\begin{array}{c}0.221^{\star \star \star} \\
(0.028)\end{array}$ & $\begin{array}{c}0.236^{\star \star \star} \\
(0.028)\end{array}$ & $\begin{array}{c}0.236^{\star \star \star} \\
(0.028)\end{array}$ & $\begin{array}{c}0.227^{\star \star \star} \\
(0.028)\end{array}$ & $\begin{array}{c}0.242^{\star \star *} \\
(0.028)\end{array}$ \\
\hline Medium Size Dummy (10 to 50 Workers) & $\begin{array}{c}0.309 * \star \star \\
(0.044)\end{array}$ & $\begin{array}{c}0.304^{\star \star \star} \\
(0.044)\end{array}$ & $\begin{array}{c}0.312^{\star \star \star} \\
(0.044)\end{array}$ & $\begin{array}{c}0.306^{\star \star \star} \\
(0.044)\end{array}$ & $\begin{array}{c}0.302^{\star \star \star} \\
(0.044)\end{array}$ & $\begin{array}{c}0.310^{\star \star \star} \\
(0.044)\end{array}$ \\
\hline Small Size Dummy (Less than 10 Workers) & $\begin{array}{c}0.248^{\star \star \star} \\
(0.053)\end{array}$ & $\begin{array}{c}0.244^{\star \star \star} \\
(0.052)\end{array}$ & $\begin{array}{c}0.220^{\star \star \star} \\
(0.051)\end{array}$ & $\begin{array}{c}0.252^{\star \star \star} \\
(0.052)\end{array}$ & $\begin{array}{c}0.248^{\star \star \star} \\
(0.052)\end{array}$ & $\begin{array}{c}0.226^{\star * *} \\
(0.050)\end{array}$ \\
\hline Dummy for Firms Aged 5 to 10 Years Old & $\begin{array}{c}0.095^{\star \star \star} \\
(0.024)\end{array}$ & $\begin{array}{c}0.089 * \star \star \\
(0.024)\end{array}$ & $\begin{array}{c}0.070 * \star \star \\
(0.025)\end{array}$ & $\begin{array}{c}0.096 * \star \star \\
(0.024)\end{array}$ & $\begin{array}{c}0.090 * \star \star \\
(0.024)\end{array}$ & $\begin{array}{c}0.070 \star \star \star \\
(0.025)\end{array}$ \\
\hline Dummy for Firms Aged 10 to 20 Years Old & $\begin{array}{c}0.142^{\star \star \star} \\
(0.025)\end{array}$ & $\begin{array}{c}0.135^{\star \star \star} \\
(0.025)\end{array}$ & $\begin{array}{c}0.083^{\star \star \star} \\
(0.028)\end{array}$ & $\begin{array}{c}0.151^{\star \star \star} \\
(0.026)\end{array}$ & $\begin{array}{c}0.144^{\star \star \star} \\
(0.026)\end{array}$ & $\begin{array}{c}0.092^{\star \star \star} \\
(0.029)\end{array}$ \\
\hline Dummy for Firms Aged 20 to 40 Years Old & $\begin{array}{c}0.140^{\star \star \star} \\
(0.031)\end{array}$ & $\begin{array}{c}0.142^{\star \star \star} \\
(0.031)\end{array}$ & $\begin{array}{l}0.062^{\star} \\
(0.034)\end{array}$ & $\begin{array}{c}0.147^{\star \star \star} \\
(0.031)\end{array}$ & $\begin{array}{c}0.148^{\star \star \star} \\
(0.032)\end{array}$ & $\begin{array}{l}0.069 * \star \\
(0.034)\end{array}$ \\
\hline Dummy for Firms Aged More than 40 Years Old & $\begin{array}{c}0.036 \\
(0.034)\end{array}$ & $\begin{array}{c}0.043 \\
(0.034)\end{array}$ & $\begin{array}{c}-0.02 \\
(0.036)\end{array}$ & $\begin{array}{c}0.034 \\
(0.035)\end{array}$ & $\begin{array}{c}0.041 \\
(0.035)\end{array}$ & $\begin{array}{c}-0.021 \\
(0.036)\end{array}$ \\
\hline Skilled Workers Share & $\begin{array}{c}0.116^{\star \star \star} \\
(0.042)\end{array}$ & $\begin{array}{c}0.124^{\star \star \star} \\
(0.042)\end{array}$ & $\begin{array}{l}0.105^{\star \star} \\
(0.041)\end{array}$ & $\begin{array}{c}0.115^{\star \star \star} \\
(0.042)\end{array}$ & $\begin{array}{l}0.122^{\star \star \star} \\
(0.042)\end{array}$ & $\begin{array}{l}0.103^{\star \star} \\
(0.041)\end{array}$ \\
\hline Dummy for Managers with Post-Graduate Education & $\begin{array}{c}0.023 \\
(0.015)\end{array}$ & $\begin{array}{c}0.023 \\
(0.015)\end{array}$ & $\begin{array}{l}0.031^{\star *} \\
(0.015)\end{array}$ & $\begin{array}{c}0.025^{\star} \\
(0.015)\end{array}$ & $\begin{array}{c}0.025^{\star} \\
(0.015)\end{array}$ & $\begin{array}{l}0.033^{\star *} \\
(0.015)\end{array}$ \\
\hline Manager Years of Experience (log) & $\begin{array}{l}0.014^{*} \\
(0.009)\end{array}$ & $\begin{array}{l}0.015^{\star} \\
(0.008)\end{array}$ & $\begin{array}{c}0.012 \\
(0.008)\end{array}$ & $\begin{array}{c}0.014 \\
(0.009)\end{array}$ & $\begin{array}{c}0.015^{\star} \\
(0.009)\end{array}$ & $\begin{array}{c}0.011 \\
(0.009)\end{array}$ \\
\hline Foreign-Owned Dummy & $\begin{array}{l}0.08{ }^{*} \\
(0.048)\end{array}$ & $\begin{array}{l}0.082^{*} \\
(0.048)\end{array}$ & $\begin{array}{c}0.068 \\
(0.048)\end{array}$ & $\begin{array}{l}0.081^{*} \\
(0.047)\end{array}$ & $\begin{array}{l}0.082^{*} \\
(0.047)\end{array}$ & $\begin{array}{c}0.069 \\
(0.047)\end{array}$ \\
\hline Exporters Dummy & $\begin{array}{c}0.095^{\star \star \star} \\
(0.022)\end{array}$ & & & $\begin{array}{c}0.092^{\star \star \star} \\
(0.022)\end{array}$ & & \\
\hline Majority Exporters Dummy & & $\begin{array}{c}0.095^{\star \star \star} \\
(0.024)\end{array}$ & & & $\begin{array}{c}0.095^{\star \star \star} \\
(0.024)\end{array}$ & \\
\hline Years of Export Experience (log) & & & $\begin{array}{c}0.047^{\star * *} \\
(0.009)\end{array}$ & & & $\begin{array}{c}0.047^{\star \star \star} \\
(0.009)\end{array}$ \\
\hline Dummy for R\&D Staff & $\begin{array}{c}-0.0004 \\
(0.026)\end{array}$ & $\begin{array}{l}-0.001 \\
(0.026)\end{array}$ & $\begin{array}{c}0.001 \\
(0.026)\end{array}$ & $\begin{array}{c}0.005 \\
(0.019)\end{array}$ & $\begin{array}{c}0.002 \\
(0.019)\end{array}$ & $\begin{array}{c}0.01 \\
(0.019)\end{array}$ \\
\hline Quality Certification Dummy & $\begin{array}{c}0.056^{\star * *} \\
(0.016)\end{array}$ & $\begin{array}{c}0.060^{\star * *} \\
(0.016)\end{array}$ & $\begin{array}{c}0.056 * \star \star \\
(0.016)\end{array}$ & $\begin{array}{c}0.056 * \star \star \\
(0.016)\end{array}$ & $\begin{array}{c}0.059 * \star * \\
(0.016)\end{array}$ & $\begin{array}{c}0.055^{\star \star \star} \\
(0.016)\end{array}$ \\
\hline Perc. of Machinery Less than 5 Years Old & $\begin{array}{c}-0.099 \star \star \star \star \\
(0.029)\end{array}$ & $\begin{array}{c}-0.104^{\star \star \star} \\
(0.029)\end{array}$ & $\begin{array}{c}-0.084^{\star \star \star} \\
(0.029)\end{array}$ & $\begin{array}{c}-0.074^{\star \star \star} \\
(0.026)\end{array}$ & $\begin{array}{c}-0.079 * \star \star \\
(0.026)\end{array}$ & $\begin{array}{c}-0.059 \star * \\
(0.026)\end{array}$ \\
\hline Dummy R\&D Staff * Perc. of Machin. Less 5 Yrs. Old & $\begin{array}{l}0.0720 \\
(0.044)\end{array}$ & $\begin{array}{c}0.075^{\star} \\
(0.044)\end{array}$ & $\begin{array}{c}0.082^{*} \\
(0.045)\end{array}$ & & & \\
\hline Perc. of Computerized Machinery & $\begin{array}{c}-0.129 * \star \star \\
(0.030)\end{array}$ & $\begin{array}{c}-0.117^{\star \star \star} \\
(0.030)\end{array}$ & $\begin{array}{c}-0.134^{\star * *} \\
(0.030)\end{array}$ & $\begin{array}{c}-0.192^{\star \star \star} \\
(0.041)\end{array}$ & $\begin{array}{c}-0.186^{\star \star \star} \\
(0.041)\end{array}$ & $\begin{array}{c}-0.196 * \star \star \\
(0.041)\end{array}$ \\
\hline Dummy R\&D Staff * Perc. of Comput. Machin. & & & & $\begin{array}{c}0.154^{\star \star \star} \\
(0.054)\end{array}$ & $\begin{array}{c}0.168^{\star \star *} \\
(0.055)\end{array}$ & $\begin{array}{c}0.153^{\star * \star} \\
(0.054)\end{array}$ \\
\hline Overdraft Dummy & $\begin{array}{c}0.026^{*} \\
(0.015)\end{array}$ & $\begin{array}{c}0.027^{*} \\
(0.015)\end{array}$ & $\begin{array}{l}0.030^{\star *} \\
(0.015)\end{array}$ & $\begin{array}{c}0.027^{\star} \\
(0.015)\end{array}$ & $\begin{array}{c}0.028^{*} \\
(0.015)\end{array}$ & $\begin{array}{l}0.031^{\star *} \\
(0.015)\end{array}$ \\
\hline Loan Dummy & $\begin{array}{c}-0.060^{\star \star \star} \\
(0.015)\end{array}$ & $\begin{array}{c}-0.055^{\star \star \star} \\
(0.015)\end{array}$ & $\begin{array}{c}-0.063^{\star * *} \\
(0.015)\end{array}$ & $\begin{array}{c}-0.059 * \star \star \\
(0.015)\end{array}$ & $\begin{array}{c}-0.055^{\star \star \star} \\
(0.015)\end{array}$ & $\begin{array}{c}-0.062^{\star \star \star} \\
(0.015)\end{array}$ \\
\hline Days to Clear Customs for Imports (log) & $\begin{array}{c}0 \\
(0.041)\end{array}$ & $\begin{array}{c}0.007 \\
(0.041)\end{array}$ & $\begin{array}{l}-0.005 \\
(0.040)\end{array}$ & $\begin{array}{c}0.008 \\
(0.041)\end{array}$ & $\begin{array}{c}0.015 \\
(0.040)\end{array}$ & $\begin{array}{c}0.004 \\
(0.040)\end{array}$ \\
\hline Number of Power Interruptions (log) & $\begin{array}{c}-0.077^{\star *} \\
(0.035)\end{array}$ & $\begin{array}{c}-0.083^{* *} \\
(0.035)\end{array}$ & $\begin{array}{c}-0.086^{\star \star} \\
(0.034)\end{array}$ & $\begin{array}{l}-0.063^{\star} \\
(0.036)\end{array}$ & $\begin{array}{l}-0.068^{\star} \\
(0.036)\end{array}$ & $\begin{array}{c}-0.071^{\star *} \\
(0.034)\end{array}$ \\
\hline Perc. Manag. Time Spent Dealing with Regulation & $\begin{array}{l}0.170^{\star *} \\
(0.083)\end{array}$ & $\begin{array}{c}0.162^{\star} \\
(0.083)\end{array}$ & $\begin{array}{c}0.135^{\star} \\
(0.078)\end{array}$ & $\begin{array}{c}0.142^{*} \\
(0.086)\end{array}$ & $\begin{array}{c}0.13 \\
(0.085)\end{array}$ & $\begin{array}{c}0.109 \\
(0.081)\end{array}$ \\
\hline Avg. Perc. of Sales Paid in Bribes to Get Things Done & $\begin{array}{l}0.032^{\star \star} \\
(0.015)\end{array}$ & $\begin{array}{l}0.027^{\star} \\
(0.015)\end{array}$ & $\begin{array}{l}0.035^{\star \star} \\
(0.015)\end{array}$ & $\begin{array}{l}0.038^{\star \star} \\
(0.015)\end{array}$ & $\begin{array}{l}0.034^{\star \star} \\
(0.015)\end{array}$ & $\begin{array}{c}0.041^{\star \star \star} \\
(0.015)\end{array}$ \\
\hline Protection Payments as Perc. Sales & $\begin{array}{c}-56.124^{\star \star \star} \\
(12.314)\end{array}$ & $\begin{array}{c}-56.017^{\star \star \star} \\
(12.289)\end{array}$ & $\begin{array}{c}-55.798^{\star \star \star} \\
(12.080)\end{array}$ & $\begin{array}{c}-55.936^{\star \star \star} \\
(12.060)\end{array}$ & $\begin{array}{c}-56.057^{\star \star \star} \\
(12.042)\end{array}$ & $\begin{array}{c}-55.535^{\star \star \star} \\
(11.820)\end{array}$ \\
\hline Industry Fixed Effects & Yes & Yes & Yes & Yes & Yes & Yes \\
\hline Year Fixed Effects & Yes & Yes & Yes & Yes & Yes & Yes \\
\hline Location Fixed Effects & Yes & Yes & Yes & Yes & Yes & Yes \\
\hline Number of Observations & 2231 & 2231 & 2217 & 2231 & 2231 & 2217 \\
\hline R-squared & 0.96 & 0.96 & 0.96 & 0.96 & 0.96 & 0.96 \\
\hline
\end{tabular}

Notes: OLS estimation is used. Robust standard errors in parentheses. $* * *, * *$, and * indicate significance at $1 \%, 5 \%$, and $10 \%$ confidence levels, respectively. The omitted size category is extremely large firms (more than 500 workers) and the omitted age category is firms less than 5 years old. 


\section{Appendix}

\section{A1. Variables' and Outliers' Definitions}

The firm survey data used in the analysis covers most of the major industries in Bangladesh: ready-made garments, textiles, food, chemicals, and leather products, according to the data on Bangladesh in the UNIDO industrial database in 1997. The central registry of manufacturing firms was outdated at the time of the survey. Hence, for each industry, the sample was drawn resorting to a different data source. For the readymade garments industry, a stratified random sample was drawn based on the rich BGMEA directory of RMG firms. For the other industries, random samples were drawn based on the most recent list of firms from the corresponding business associations. Strict quality control criteria were applied during the data collection and data processing phases. However, the final dataset of 682 firms includes some anomalies. We eliminated from the estimating sample:

a) firms that report being subcontracted. These firms do not purchase materials themselves and thus do not fit into our framework of production function estimation with an optimizing firm making input and output decisions.

b) firms that were opened at the beginning of the sample period, closed during the sample period and then re-opened at the end of the sample period since they lack lagged observations on inputs and output needed for production function estimation.

c) firms that were outliers because they had year-to-year growth rates in at least one of three crucial ratios (real sales to total workers, real material costs to total workers and capital to total workers) larger (smaller) than $150 \%(-150 \%) .{ }^{51}$

d) firms with clear data entry errors in some of the production variables.

The variables used for production function estimation are defined as follows:

a) Output is given by nominal sales (converted to USD using the average exchange rate in the IFS statistics (IMF)) deflated by a firm output price index (with base 1990). This output price index is based on a survey question that asks firms to report the percent change in the price of its main products from year to year. For the few firms that do report these price changes, we deflate their sales by the average change in output price in their industry.

b) Employment is given by the total number of workers working at the firm.

c) Materials is given by nominal materials costs (converted to USD using the average exchange rate in the IFS statistics (IMF)) deflated by a firm materials price index (with base 1990). This materials price index is based on a survey question that asks firms to report the percent change in the price of its main materials from year to year. Some firms do not report data on those price changes. For the few firms that do report these price changes, we deflate their materials by the average change in output price in their industry.

d) Capital is obtained summing real investment (converted to USD using the average exchange rate in the IFS statistics (IMF)) over time using the perpetual inventory

\footnotetext{
${ }^{51}$ Due to data problems, we used different outlier criteria for firms in the leather/footwear industry: firms for which at least one of the three ratios was larger (smaller) than the industry average of the ratio plus (minus) 5 times the industry standard deviation of the ratio.
} 
method formula: $K_{i t}=(1-d) K_{i t-1}+I_{i t}$, where $d$ is a depreciation rate assumed to be equal to $10 \%$. Real investment $I_{i t}$ is obtained deflating nominal investment flows by an aggregate investment deflator. ${ }^{52}$ The initial capital stock follows Kee (2006) and is given by: $K_{i 0}=\frac{1}{2}\left(F_{i 0}+\frac{I_{i 0}}{d}\right)$, where $F_{i 0}$ and $I_{i 0}$ are, respectively, the book value of fixed assets and the real investment in the first year the firm is in the sample (both were first converted to USD using the average exchange rate in the IFS statistics (IMF)). When firms have zero investment in their first year in the sample, we replace that formula by: $K_{i 0}=F_{i 0}$.

\section{A2. Production Function Estimation}

We estimate Cobb-Douglas production function separately for each industry following the methodology proposed by Olley and Pakes (1996) which is derived from a dynamic profit maximization problem for the firm. The estimating equation is given by:

$$
\ln Y_{i t}=\beta_{L} \ln L_{i t}+\beta_{M} \ln M_{i t} \beta_{K} \ln K_{i t}+\omega_{i t}+\varepsilon_{i t} \text {, }
$$

where $i$ designates a firm and $t$ designates a year. $\mathrm{Y}_{\text {it }}$ is output, $\mathrm{L}_{\mathrm{it}}$ is labor, $\mathrm{M}_{\mathrm{it}}$ is materials, $\mathrm{K}_{\mathrm{it}}$ is capital, and $\omega_{i t}$ is productivity known to the firm, and $\varepsilon_{i t}$ is a mean-zero shock that uncorrelated with the input choices and unknown to the firm. While both $\omega_{i t}$ and $\varepsilon_{i t}$ are unknown to the researcher, $\omega_{i t}$ is a state variable to which a firm adjusts its variable input choices (labor and materials). Capital is assumed to be a state variable which is affected only by the expected value of productivity $\omega_{i t}$, conditional on productivity at $\mathrm{t}-1$. The correlation that results between the composite error $\omega_{i t}+\varepsilon_{i t}$ and the inputs causes OLS estimates of the production function coefficients to be biased.

In the first part of Olley and Pakes' methodology, we obtain coefficients on the variable inputs using semi-parametric techniques. We use investment - an observable firm characteristic - to proxy for the unobservable firm productivity. From the dynamic profit maximizing problem, firm investment $\mathrm{I}_{\mathrm{it}}$ depends on the state variables -capital and firm productivity:

$$
I_{i t}=I_{t}\left(K_{i t}, \omega_{i t}\right) \text {. }
$$

This investment function is assumed to monotonically increasing in productivity, conditional on capital. Thus, it can be inverted to express the unobserved productivity as a function of observables -capital and investment:

$$
\omega_{i t}=\omega_{t}\left(K_{i t}, I_{i t}\right) \text {. }
$$

Inserting this expression for productivity into Eq. (A1) results in the semi-parametric equation:

where

$$
\ln Y_{i t}=\beta_{L} \ln L_{i t}+\beta_{M} \ln M_{i t}+\phi_{t}\left(K_{i t}, I_{i t}, \omega_{i t}\right)+\varepsilon_{i t},
$$

$$
\phi_{t}\left(K_{i t}, I_{i t}, \omega_{i t}\right)=\beta_{K} K_{i t}+\omega_{t}\left(K_{i t}, I_{i t}\right) .
$$

52 This deflator is obtained as the ratio of gross fixed capital formation in current prices to gross fixed capital formation in constant prices and transformed into a 1990 base year. Gross fixed capital formation data is taken from the World Bank’s World Development Indicators. 
Eq. (A4) is estimated by OLS, approximating the unknown function $\phi_{t}($.$) by a third-$ order polynomial on $\mathrm{K}_{\mathrm{it}}$ and $\mathrm{I}_{\mathrm{it}}$. Since the error term in Eq. (A4) is uncorrelated with the regressors, unbiased coefficients on labor and materials $\left(\bar{\beta}_{L}, \bar{\beta}_{M}\right)$ are obtained.

In the second part of Olley and Pakes' methodology, we obtain the coefficient on capital. We consider the expectation of $\ln Y_{i t+1}-\beta_{L} \ln L_{i t+1}-\beta_{M} \ln M_{i t+1}$ conditional on information available at $\mathrm{t}^{53}$, $E\left[\ln Y_{i t+1}-\beta_{L} \ln L_{i t+1}-\beta_{M} \ln M_{i t+1} / K_{i t+1}\right]=\beta_{K} K_{i t+1}+E\left[\omega_{i t+1} / \omega_{i t}\right]=\beta_{K} K_{i t+1}+g\left(\omega_{i t}\right)$

and assume that productivity follows a first-order Markov process: $\omega_{i t+1}=E\left[\omega_{i t+1} / \omega_{i t}\right]+\mu_{i t+1}$ where $\mu_{i t+1}$ is the unexpected part of productivity. Using this assumption and the estimated coefficients on labor and materials from the first part of the estimation, Eq. (A5) can be rewritten as a function of only $\mathrm{I}_{\mathrm{it}}$ and $\mathrm{K}_{\mathrm{it}}$ :

$$
\ln Y_{i t+1}-\bar{\beta}_{L} \ln L_{i t+1}-\bar{\beta}_{M} \ln M_{i t+1}=\beta_{K} K_{i t+1}+g\left(\bar{P}_{i t}-\beta_{K} K_{i t}\right)+\mu_{i t+1}+\varepsilon_{i t+1},
$$

where $g\left(\omega_{i t}\right)=g\left(\phi_{t}\left(K_{i t}, I_{i t}, \omega_{i t}\right)-\beta_{K} K_{i t}\right)=g\left(\bar{P}_{i t}-\beta_{K} K_{i t}\right)$ follows from Eq. (A4) replacing the unknown function $\phi_{t}\left(\right.$.) by its estimate $\bar{P}_{i t}$ given by the aforementioned polynomial evaluated at the estimated coefficients. Since $\mathrm{K}_{\mathrm{it}+1}$ is known at the beginning of year $\mathrm{t}+1$ and $\mu_{i t+1}$ is mean independent of all variables known at the beginning of year $\mathrm{t}+1$, this implies that $\mathrm{K}_{\mathrm{it}+1}$ is uncorrelated with $\mu_{i t+1}$. Thus, an unbiased estimate of the coefficient on capital can be obtained estimating Eq. (A6) by non-linear least squares. If the sum of the production function coefficients on labor, materials, and capital is larger than one, then the industry has increasing returns to scale.

Using the consistent production function estimates, firm TFP measures for each firm and year are computed as the residuals from Eq. (A1): $p_{i t}=\ln Y_{i t}-\beta_{L} \ln L_{i t}-\beta_{M} \ln M_{i t}-\beta_{K} K_{i t}$. The inversion of the investment function (Eq. (A2)) can be done only if investment is positive in all years. Thus, for each industry, the production function coefficients are estimated based on a sample that includes only firms with positive investment in all years. ${ }^{54}$ However, following Olley and Pakes (1996), we compute TFP measures for all firms (that are not outliers) even those with zero investment in some or all years.

Industry TFP is obtained as the weighted average of firm TFP, with weights given by firms' shares in total sales of the industry as follows: $P_{i t}^{j}=\sum_{i=1}^{N_{j}} s_{i t}^{j} * p_{i t}^{j}$, where $s_{i t}^{j}$ represents the share of firm $i$ sales in total sales of its industry $j$ in year $t$. Based on these industry TFP measures, Olley and Pakes (1996) proposed the following decomposition: $P_{i t}^{j}=\overline{p_{i t}^{j}}+\sum_{i=1}^{N_{j}}\left(s_{i t}^{j}-\overline{s_{i t}^{j}}\right) *\left(p_{i t}^{j}-\overline{p_{i t}^{j}}\right)$, where $\overline{p_{i t}^{j}}$ is the unweighted average

\footnotetext{
${ }^{53} K_{i t+1}$ is known at $t$ since capital follows the accumulation equation: $K_{i t+1}=(1-d) * K_{i t}+I_{i t}$, where $\mathrm{d}$ is a depreciation rate.

${ }^{54}$ An exception is the leather industry, where due to the small sample size we include all firms (even those with zero investment) in the production function estimation.
} 
firm TFP $\left(\overline{p_{i t}^{j}}=\sum_{i=1}^{N_{j}} p_{i t}^{j}\right)$ in the industry and year and $\overline{s_{i t}^{j}}$ is the average sales share in the industry and year. The second term in the expression for $P_{i t}^{j}$ represents the covariance between firms' TFP and firms’ sales shares.

Appendix Table 1: Sample Composition

\begin{tabular}{|c|c|c|c|c|c|c|}
\hline \multirow[b]{2}{*}{ Industry } & \multirow[b]{2}{*}{$\begin{array}{l}\text { Number of } \\
\text { Firms }\end{array}$} & \multicolumn{5}{|c|}{ Size Distribution (\% of Firms) } \\
\hline & & $\begin{array}{c}\text { Small } \\
\text { (<10 workers) }\end{array}$ & $\begin{array}{c}\text { Medium } \\
(10-50 \\
\text { workers })\end{array}$ & $\begin{array}{c}\text { Relatively } \\
\text { Large (50-150 } \\
\text { workers) }\end{array}$ & $\begin{array}{l}\text { Very Large } \\
\text { (150-500 } \\
\text { workers) }\end{array}$ & $\begin{array}{c}\text { Extremely } \\
\text { Large (>500 } \\
\text { workers) }\end{array}$ \\
\hline Pharmaceuticals & 51 & & $5.9 \%$ & $15.7 \%$ & $45.1 \%$ & $33.3 \%$ \\
\hline Food & 88 & $1.1 \%$ & $12.5 \%$ & $44.3 \%$ & $33.0 \%$ & $9.1 \%$ \\
\hline Ready-Made Garments & 276 & & $0.4 \%$ & $0.7 \%$ & $48.6 \%$ & $50.4 \%$ \\
\hline Leather/Footwear & 24 & $4.2 \%$ & $20.8 \%$ & $33.3 \%$ & $29.2 \%$ & $12.5 \%$ \\
\hline Textiles & 136 & & $2.2 \%$ & $16.9 \%$ & $44.1 \%$ & $36.8 \%$ \\
\hline Total & 575 & $0.4 \%$ & $4.0 \%$ & $13.9 \%$ & $44.0 \%$ & $37.7 \%$ \\
\hline \multirow[b]{2}{*}{ Industry } & \multicolumn{5}{|c|}{ Age Distribution (\% of Firms) } & \\
\hline & $\begin{array}{c}<5 \text { Years } \\
\text { Old }\end{array}$ & $\begin{array}{l}\text { 5-10 Years } \\
\text { Old }\end{array}$ & $\begin{array}{l}\text { 10-20 Years } \\
\text { Old }\end{array}$ & $\begin{array}{l}\text { 20-40 Years } \\
\text { Old }\end{array}$ & $\begin{array}{l}>40 \text { Years } \\
\text { Old }\end{array}$ & \\
\hline Pharmaceuticals & $15.7 \%$ & $11.8 \%$ & $29.4 \%$ & $29.4 \%$ & $13.7 \%$ & \\
\hline Food & $26.4 \%$ & $10.3 \%$ & $35.6 \%$ & $25.3 \%$ & $2.3 \%$ & \\
\hline Garments & $27.5 \%$ & $27.5 \%$ & $35.9 \%$ & $8.3 \%$ & $0.7 \%$ & \\
\hline Leather/Footwear & & $8.3 \%$ & $25.0 \%$ & $54.2 \%$ & $12.5 \%$ & \\
\hline Textiles & $29.4 \%$ & $27.2 \%$ & $27.2 \%$ & $11.0 \%$ & $5.2 \%$ & \\
\hline Total & $25.6 \%$ & $22.7 \%$ & $32.8 \%$ & $15.3 \%$ & $3.7 \%$ & \\
\hline \multirow[b]{2}{*}{ Industry } & \multicolumn{6}{|c|}{ Location (\% of Firms) } \\
\hline & Dhaka & $\begin{array}{c}\text { Dhaka Export } \\
\text { Processing } \\
\text { Zone }\end{array}$ & Chittagong & $\begin{array}{l}\text { Chittagong } \\
\text { Export } \\
\text { Processing } \\
\text { Zone } \\
\end{array}$ & Khulna & Other \\
\hline Pharmaceuticals & $72.6 \%$ & & $5.9 \%$ & & & $21.6 \%$ \\
\hline Food & $28.4 \%$ & & $39.8 \%$ & & $4.6 \%$ & $27.3 \%$ \\
\hline Garments & $62.3 \%$ & $4.7 \%$ & $15.9 \%$ & $9.8 \%$ & & $7.3 \%$ \\
\hline Leather/Footwear & $87.5 \%$ & $4.2 \%$ & $4.2 \%$ & & & $4.2 \%$ \\
\hline Textiles & $29.4 \%$ & $1.5 \%$ & $9.6 \%$ & $3.7 \%$ & & $55.9 \%$ \\
\hline Total & $51.3 \%$ & $2.8 \%$ & $16.7 \%$ & $5.6 \%$ & $0.7 \%$ & $23.0 \%$ \\
\hline
\end{tabular}

Notes: The composition of the sample in terms of size and age is based on data for 2003. One firm in the food industry is excluded from the age distribution calculations, since it does not report data on its year of establishment. 


\section{Appendix Table 2: Summary Statistics of Production Variables}

\begin{tabular}{|c|c|c|c|c|c|c|c|}
\hline \multicolumn{4}{|c|}{ Pharmaceuticals Industry } & \multicolumn{4}{|c|}{ Leather/Footwear Industry } \\
\hline Sales per Worker & 13138 & 8158 & 0.86 & Sales per Worker & 30294 & 24323 & 0.81 \\
\hline Number of Workers & 430 & 305 & 0.82 & Number of Workers & 190 & 110 & 1.11 \\
\hline Sales & 7029916 & 2382675 & 1.54 & Sales & 5133673 & 3179985 & 1.28 \\
\hline Real Investment & 665290 & 61222 & 3.95 & Real Investment & 62390 & 14689 & 2.02 \\
\hline Capital Stock & 5490111 & 1532507 & 2.83 & Capital Stock & 1641942 & 1448466 & 0.90 \\
\hline \multicolumn{4}{|l|}{ Food Industry } & Textiles Industry & & & \\
\hline & Average & Median & $\begin{array}{c}\text { Coefficient } \\
\text { of } \\
\text { Variation }\end{array}$ & & Average & Median & $\begin{array}{c}\text { Coefficient } \\
\text { of } \\
\text { Variation }\end{array}$ \\
\hline Number of Workers & 167 & 130 & 0.95 & Number of Workers & 627 & 330 & 1.37 \\
\hline Sales & 5112741 & 1940785 & 2.10 & Sales & 6082233 & 2886147 & 1.40 \\
\hline Materials Costs & 3881596 & 1273082 & 2.26 & Materials Costs & 3966957 & 1759238 & 1.37 \\
\hline Real Investment & 203379 & 20947 & 3.64 & Real Investment & 453542 & 57800 & 3.80 \\
\hline Capital Stock & 2481127 & 908399 & 1.83 & Capital Stock & 6133218 & 2222081 & 1.90 \\
\hline \multicolumn{8}{|c|}{ Ready-Made Garments Industry } \\
\hline & Average & Median & $\begin{array}{c}\text { Coefficient } \\
\text { of } \\
\text { Variation }\end{array}$ & & & & \\
\hline
\end{tabular}

Notes: The summary statistics are calculated for the estimating sample based on observations for the years 1999-2003 in each industry. The monetary values are expressed in 1999 U.S. dollars. IT stands for information technology. 


\section{Appendix Table 3: Summary Statistics on Determinants of TFP \\ Panel A. Human Capital}

\begin{tabular}{lcc}
\hline Pharmaceuticals Industry & Average & Median \\
\hline Perc. of Skilled Workers at Firm & $43.7 \%$ & $37.1 \%$ \\
Perc. of Workers with College Educ. at Firm & $24.4 \%$ & $20.0 \%$ \\
Perc. of Managers with Post-Graduate Educ. & $76.0 \%$ & \\
Nb.Years of Experience of Manager & 10.8 & 8.0 \\
\hline Food Industry & Average & Median \\
\hline Perc. of Skilled Workers at Firm & $62.7 \%$ & $67.0 \%$ \\
Perc. of Workers with College Educ. at Firm & $8.5 \%$ & $3.0 \%$ \\
Perc. of Managers with Post-Graduate Educ. & $71.6 \%$ & \\
Nb.Years of Experience of Manager & 10.1 & 8.0 \\
\hline & & \\
\hline Ready-Made Garments Industry & Average & Median \\
\hline Perc. of Skilled Workers at Firm & $67.4 \%$ & $68.5 \%$ \\
Perc. of Workers with College Educ. at Firm & $3.9 \%$ & $3.0 \%$ \\
Perc. of Managers with Post-Graduate Educ. & $54.3 \%$ & \\
Nb.Years of Experience of Manager & 8.1 & 6.0 \\
\hline
\end{tabular}

\begin{tabular}{lcc}
\hline Leather/Footwear Industry & Average & Median \\
\hline Perc. of Skilled Workers at Firm & $62.0 \%$ & $62.3 \%$ \\
Perc. of Workers with College Educ. at Firm & $3.2 \%$ & $2.0 \%$ \\
Perc. of Managers with Post-Graduate Educ. & $41.7 \%$ & \\
Nb.Years of Experience of Manager & 17.0 & 17.5 \\
\hline \hline Textiles Industry & Average & Median \\
\hline Perc. of Skilled Workers at Firm & $67.1 \%$ & $68.1 \%$ \\
Perc. of Workers with College Educ. at Firm & $5.1 \%$ & $3.0 \%$ \\
Perc. of Managers with Post-Graduate Educ. & $70.4 \%$ & \\
Nb.Years of Experience of Manager & 7.9 & 6.0 \\
\hline
\end{tabular}

\section{Panel B. International Integration}

\begin{tabular}{lcc}
\hline Pharmaceuticals Industry & Average & Median \\
\hline Perc. of Foreign-Owned Firms & $10.0 \%$ & \\
Perc. of Exporters & $26.0 \%$ & \\
Perc. of Majority Exporters & $0.0 \%$ & \\
Export Share & $1.8 \%$ & $0.0 \%$ \\
Nb. of Years of Export Exper. & 1.9 & 0.0 \\
\hline \hline Food Industry & Average & Median \\
\hline Perc. of Foreign-Owned Firms & $7.4 \%$ & \\
Perc. of Exporters & $46.9 \%$ & \\
Perc. of Majority Exporters & $42.0 \%$ & \\
Export Share & $40.6 \%$ & $0.0 \%$ \\
Nb. of Years of Export Exper. & 8.0 & 0.0 \\
\hline Ready-Made Garments Industry & Average & Median \\
\hline Perc. of Foreign-Owned Firms & $12.7 \%$ & \\
Perc. of Exporters & $97.2 \%$ & \\
Perc. of Majority Exporters & $96.4 \%$ & \multirow{2}{*}{$100.0 \%$} \\
Export Share & $97.9 \%$ & 9.0 \\
Nb. of Years of Export Exper. & 8.1 & \\
\hline
\end{tabular}

\begin{tabular}{lcc}
\hline Leather/Footwear Industry & Average & Median \\
\hline Perc. of Foreign-Owned Firms & $4.2 \%$ & \\
Perc. of Exporters & $91.7 \%$ & \\
Perc. of Majority Exporters & $91.7 \%$ & \\
Export Share & $91.5 \%$ & $100.0 \%$ \\
Nb. of Years of Export Exper. & 21.1 & 20.5 \\
\hline & & \\
\hline Textiles Industry & Average & Median \\
\hline Perc. of Foreign-Owned Firms & $8.8 \%$ & \\
Perc. of Exporters & $57.6 \%$ & \\
Perc. of Majority Exporters & $54.4 \%$ & \\
Export Share & $53.3 \%$ & $70.0 \%$ \\
Nb. of Years of Export Exper. & 5.8 & 2.0 \\
\hline
\end{tabular}

Panel C. Technology

\begin{tabular}{lcc}
\hline Pharmaceuticals Industry & Average & Median \\
\hline Perc. of Firms with Loan & $62.0 \%$ & \\
Perc. of Firms with Overdraft & $70.0 \%$ & \\
Perc. of Working Cap. Financed by Banks & $34.1 \%$ & $20.0 \%$ \\
Perc. of InvestmentsFinanced by Banks & $25.0 \%$ & $0.0 \%$ \\
\hline \hline Food Industry & Average & Median \\
\hline Perc. of Firms with Loan & $61.7 \%$ & \\
Perc. of Firms with Overdraft & $67.9 \%$ & \\
Perc. of Working Cap. Financed by Banks & $36.5 \%$ & $36.5 \%$ \\
Perc. of InvestmentsFinanced by Banks & $14.4 \%$ & $0.0 \%$ \\
\hline & & \\
\hline Ready-Made Garments Industry & Average & Median \\
\hline Perc. of Firms with Loan & $29.8 \%$ & \\
Perc. of Firms with Overdraft & $60.4 \%$ & \\
Perc. of Working Cap. Financed by Banks & $16.3 \%$ & $0.0 \%$ \\
Perc. of InvestmentsFinanced by Banks & $10.6 \%$ & $0.0 \%$ \\
\hline
\end{tabular}

\begin{tabular}{lcc}
\hline Leather/Footwear Industry & Average & Median \\
\hline Perc. of Firms with Loan & $75.0 \%$ & \\
Perc. of Firms with Overdraft & $83.3 \%$ & \\
Perc. of Working Cap. Financed by Banks & $48.9 \%$ & $45.1 \%$ \\
Perc. of InvestmentsFinanced by Banks & $6.3 \%$ & $0.0 \%$ \\
\hline \hline Textiles Industry & Average & Median \\
\hline Perc. of Firms with Loan & $68.8 \%$ & \\
Perc. of Firms with Overdraft & $77.6 \%$ & \\
Perc. of Working Cap. Financed by Banks & $38.1 \%$ & $40.0 \%$ \\
Perc. of InvestmentsFinanced by Banks & $29.6 \%$ & $0.0 \%$ \\
\hline
\end{tabular}




\section{Panel D. Finance}

\begin{tabular}{lcc}
\hline Pharmaceuticals Industry & Average & Median \\
\hline Perc. of Firms with Loan & $62.0 \%$ & \\
Perc. of Firms with Overdraft & $70.0 \%$ & \\
Perc. of Working Cap. Financed by Banks & $34.1 \%$ & $20.0 \%$ \\
Perc. of InvestmentsFinanced by Banks & $25.0 \%$ & $0.0 \%$ \\
\hline \hline & Average & Median \\
\hline Food Industry & $61.7 \%$ & \\
\hline Perc. of Firms with Loan & $67.9 \%$ & \\
Perc. of Firms with Overdraft & $36.5 \%$ & $36.5 \%$ \\
Perc. of Working Cap. Financed by Banks & $14.4 \%$ & $0.0 \%$ \\
Perc. of InvestmentsFinanced by Banks & & \\
\hline & Average & \multirow{2}{*}{ Median } \\
\hline Ready-Made Garments Industry & $29.8 \%$ & \\
\hline Perc. of Firms with Loan & $60.4 \%$ & \\
Perc. of Firms with Overdraft & $16.3 \%$ & $0.0 \%$ \\
Perc. of Working Cap. Financed by Banks & $10.6 \%$ & $0.0 \%$ \\
\hline Perc. of InvestmentsFinanced by Banks &
\end{tabular}

\begin{tabular}{lcc}
\hline Leather/Footwear Industry & Average & Median \\
\hline Perc. of Firms with Loan & $75.0 \%$ & \\
Perc. of Firms with Overdraft & $83.3 \%$ & \\
Perc. of Working Cap. Financed by Banks & $48.9 \%$ & $45.1 \%$ \\
Perc. of InvestmentsFinanced by Banks & $6.3 \%$ & $0.0 \%$ \\
\hline & Average & Median \\
\hline Textiles Industry & $68.8 \%$ & \\
\hline Perc. of Firms with Loan & $77.6 \%$ & \\
Perc. of Firms with Overdraft & $38.1 \%$ & $40.0 \%$ \\
Perc. of Working Cap. Financed by Banks & $29.6 \%$ & $0.0 \%$ \\
Perc. of InvestmentsFinanced by Banks & & \\
\hline
\end{tabular}

\section{Panel E. Business Environment}

\begin{tabular}{lcc}
\hline Pharmaceuticals Industry & Average & Median \\
\hline Avg. Nb. of Days to Clear Customs for Imports & 5.2 & 3.0 \\
Perc. Time Spent by Manager Dealing with Regul. & $20.3 \%$ & $11.0 \%$ \\
Number of Power Outages & 379.9 & 255.0 \\
Perc. of Firms with Generator & $88.0 \%$ & \\
Perc. of Firms Paying Bribes to Get Things Done & $80.0 \%$ & \\
Perc. Sales Paid in Bribes to Get Things Done & $0.6 \%$ & $0.1 \%$ \\
Protection Payments as Perc. Sales & $0.01 \%$ & $0.0 \%$ \\
\hline Food Industry & Average & Median \\
\hline Avg. Nb. of Days to Clear Customs for Imports & 2.9 & 3.0 \\
Perc. Time Spent by Manager Dealing with Regul. & $25.3 \%$ & $20.0 \%$ \\
Number of Power Outages & 559.6 & 450.0 \\
Perc. of Firms with Generator & $86.4 \%$ & \\
Perc. of Firms Paying Bribes to Get Things Done & $82.7 \%$ & \\
Perc. Sales Paid in Bribes to Get Things Done & $0.7 \%$ & $0.1 \%$ \\
Protection Payments as Perc. Sales & $0.02 \%$ & $0.0 \%$ \\
\hline Ready-Made Garments Industry & & \\
\hline Read. & Average & Median \\
\hline Avg. Nb. of Days to Clear Customs for Imports & 4.5 & 3.0 \\
Perc. Time Spent by Manager Dealing with Regul. & $25.1 \%$ & $20.0 \%$ \\
Number of Power Outages & 438.2 & 360.0 \\
Perc. of Firms with Generator & $84.1 \%$ & \\
Perc. of Firms Paying Bribes to Get Things Done & $92.2 \%$ & \\
Perc. Sales Paid in Bribes to Get Things Done & $1.3 \%$ & $0.5 \%$ \\
Protection Payments as Perc. Sales & $0.02 \%$ & $0.0 \%$ \\
\hline
\end{tabular}

\begin{tabular}{lcc}
\hline Leather/Footwear Industry & Average & Median \\
\hline Avg. Nb. of Days to Clear Customs for Imports & 3.3 & 3.0 \\
Perc. Time Spent by Manager Dealing with Regul. & $27.0 \%$ & $12.5 \%$ \\
Number of Power Outages & 885.2 & 800.0 \\
Perc. of Firms with Generator & $91.7 \%$ & \\
Perc. of Firms Paying Bribes to Get Things Done & $100.0 \%$ & \\
Perc. Sales Paid in Bribes to Get Things Done & $0.5 \%$ & $0.0 \%$ \\
Protection Payments as Perc. Sales & $0.002 \%$ & $0.0 \%$ \\
\hline & & \\
\hline Textiles Industry & Average & Median \\
\hline Avg. Nb. of Days to Clear Customs for Imports & 3.9 & 3.0 \\
Perc. Time Spent by Manager Dealing with Regul. & $18.2 \%$ & $15.0 \%$ \\
Number of Power Outages & 437.4 & 341.0 \\
Perc. of Firms with Generator & $88.0 \%$ & \\
Perc. of Firms Paying Bribes to Get Things Done & $89.6 \%$ & \\
Perc. Sales Paid in Bribes to Get Things Done & $0.6 \%$ & $0.1 \%$ \\
Protection Payments as Perc. Sales & $0.01 \%$ & $0.0 \%$ \\
\hline
\end{tabular}




\section{Appendix Table 4: TFP Regressions Including a Single Determinant}

\begin{tabular}{|c|c|c|c|c|c|c|c|c|c|c|c|}
\hline & \multicolumn{11}{|c|}{ Dependent Variable is log of TFP } \\
\hline & (1) & (2) & (3) & (4) & (5) & (6) & (7) & (8) & (9) & (10) & (11) \\
\hline Very Large Dummy (150 to 500 Workers) & $\begin{array}{l}0.021^{*} \\
(0.012)\end{array}$ & & $\begin{array}{c}0.034^{\star \star \star} \\
(0.011)\end{array}$ & $\begin{array}{c}0.034^{\star \star \star} \\
(0.012)\end{array}$ & $\begin{array}{c}0.033^{\star \star \star} \\
(0.012)\end{array}$ & $\begin{array}{c}0.030^{\star \star \star} \\
(0.012)\end{array}$ & $\begin{array}{c}0.037^{\star \star \star} \\
(0.012)\end{array}$ & $\begin{array}{c}0.033^{\star \star \star} \\
(0.011)\end{array}$ & $\begin{array}{c}0.033^{\star \star \star} \\
(0.012)\end{array}$ & $\begin{array}{c}0.043^{\star \star \star} \\
(0.011)\end{array}$ & $\begin{array}{c}0.034^{\star \star \star} \\
(0.011)\end{array}$ \\
\hline Relatively Large Dummy (50 to 150 Workers) & $\begin{array}{c}0.202^{\star \star \star} \\
(0.026)\end{array}$ & & $\begin{array}{c}0.204^{\star \star \star} \\
(0.025)\end{array}$ & $\begin{array}{c}0.216^{\star \star \star} \\
(0.025)\end{array}$ & $\begin{array}{c}0.215^{\star \star \star} \\
(0.026)\end{array}$ & $\begin{array}{c}0.207^{\star \star \star} \\
(0.026)\end{array}$ & $\begin{array}{c}0.222^{\star \star \star} \\
(0.025)\end{array}$ & $\begin{array}{c}0.216^{\star \star \star} \\
(0.026)\end{array}$ & $\begin{array}{l}0.212^{\star \star \star} \\
(0.025)\end{array}$ & $\begin{array}{c}0.225^{\star \star \star} \\
(0.025)\end{array}$ & $\begin{array}{c}0.221^{\star * *} \\
(0.026)\end{array}$ \\
\hline Medium Size Dummy (10 to 50 Workers) & $\begin{array}{c}0.160 \star \star \star \\
(0.049)\end{array}$ & & $\begin{array}{l}0.179 \star \star \star \\
(0.047)\end{array}$ & $\begin{array}{c}0.186^{\star \star \star} \\
(0.048)\end{array}$ & $\begin{array}{l}0.191^{\star \star \star} \\
(0.048)\end{array}$ & $\begin{array}{c}0.267^{\star \star \star} \\
(0.041)\end{array}$ & $\begin{array}{l}0.200^{\star \star \star} \\
(0.048)\end{array}$ & $\begin{array}{c}0.201 \star \star \star \\
(0.048)\end{array}$ & $\begin{array}{l}0.208^{\star \star \star} \\
(0.047)\end{array}$ & $\begin{array}{c}0.225^{\star \star \star} \\
(0.047)\end{array}$ & $\begin{array}{c}0.195^{\star \star \star} \\
(0.048)\end{array}$ \\
\hline Small Size Dummy (Less than 10 Workers) & $\begin{array}{c}0.133^{\star \star *} \\
(0.046)\end{array}$ & & $\begin{array}{c}0.175^{\star \star \star} \\
(0.055)\end{array}$ & $\begin{array}{c}0.154^{\star \star \star *} \\
(0.047)\end{array}$ & $\begin{array}{c}0.148^{\star \star \star} \\
(0.047)\end{array}$ & $\begin{array}{c}0.145^{\star \star \star} \\
(0.046)\end{array}$ & $\begin{array}{l}0.159^{\star \star \star} \\
(0.047)\end{array}$ & $\begin{array}{c}0.166^{\star \star \star} \\
(0.049)\end{array}$ & $\begin{array}{l}0.192^{\star \star \star} \\
(0.046)\end{array}$ & $\begin{array}{c}0.171^{\star \star \star} \\
(0.047)\end{array}$ & $\begin{array}{l}0.154^{\star \star \star} \\
(0.048)\end{array}$ \\
\hline Dummy for Firms Aged 5 to 10 Years Old & & $\begin{array}{c}0.171^{\star \star \star} \\
(0.022)\end{array}$ & $\begin{array}{c}0.176^{\star \star \star} \\
(0.022)\end{array}$ & $\begin{array}{c}0.182^{\star \star \star} \\
(0.022)\end{array}$ & $\begin{array}{c}0.180^{\star \star \star} \\
(0.022)\end{array}$ & $\begin{array}{c}0.170^{\star \star \star} \\
(0.023)\end{array}$ & $\begin{array}{l}0.180^{\star \star \star} \\
(0.022)\end{array}$ & $\begin{array}{c}0.182^{\star \star \star} \\
(0.022)\end{array}$ & $\begin{array}{c}0.180^{\star \star \star} \\
(0.022)\end{array}$ & $\begin{array}{c}0.146^{\star \star \star} \\
(0.024)\end{array}$ & $\begin{array}{l}0.181^{\star \star \star} \\
(0.022)\end{array}$ \\
\hline Dummy for Firms Aged 10 to 20 Years Old & & $\begin{array}{c}0.222^{\star \star \star} \\
(0.023)\end{array}$ & $\begin{array}{c}0.228^{\star \star \star} \\
(0.023)\end{array}$ & $\begin{array}{c}0.232^{\star \star \star} \\
(0.023)\end{array}$ & $\begin{array}{c}0.229^{\star \star \star} \\
(0.023)\end{array}$ & $\begin{array}{c}0.223^{\star \star \star} \\
(0.023)\end{array}$ & $\begin{array}{c}0.231^{\star \star \star} \\
(0.023)\end{array}$ & $\begin{array}{c}0.228^{\star \star \star} \\
(0.023)\end{array}$ & $\begin{array}{l}0.220^{\star \star \star} \\
(0.023)\end{array}$ & $\begin{array}{c}0.149^{\star \star \star} \\
(0.027)\end{array}$ & $\begin{array}{c}0.230^{\star \star \star} \\
(0.023)\end{array}$ \\
\hline Dummy for Firms Aged 20 to 40 Years Old & & $\begin{array}{l}0.215^{\star \star \star} \\
(0.028)\end{array}$ & $\begin{array}{c}0.242^{\star \star \star} \\
(0.029)\end{array}$ & $\begin{array}{c}0.237^{\star \star \star} \\
(0.029)\end{array}$ & $\begin{array}{c}0.234^{\star \star \star} \\
(0.029)\end{array}$ & $\begin{array}{c}0.220^{\star \star \star} \\
(0.031)\end{array}$ & $\begin{array}{c}0.233^{\star \star \star} \\
(0.029)\end{array}$ & $\begin{array}{l}0.230 \star \star \star \\
(0.028)\end{array}$ & $\begin{array}{l}0.225^{\star \star \star} \\
(0.028)\end{array}$ & $\begin{array}{c}0.125^{\star \star \star} \\
(0.033)\end{array}$ & $\begin{array}{c}0.234^{\star \star *} \\
(0.029)\end{array}$ \\
\hline Dummy for Firms Aged More than 40 Years Old & & $\begin{array}{l}0.089^{\star \star \star} \\
(0.031)\end{array}$ & $\begin{array}{c}0.132^{\star \star \star} \\
(0.031)\end{array}$ & $\begin{array}{c}0.105^{\star \star \star \star} \\
(0.031)\end{array}$ & $\begin{array}{l}0.110^{\star \star \star} \\
(0.031)\end{array}$ & $\begin{array}{c}0.116^{\star \star \star} \\
(0.032)\end{array}$ & $\begin{array}{l}0.113^{\star \star \star} \\
(0.031)\end{array}$ & $\begin{array}{c}0.111^{\star \star \star} \\
(0.031)\end{array}$ & $\begin{array}{c}0.108^{\star \star \star} \\
(0.031)\end{array}$ & $\begin{array}{c}0.031 \\
(0.034)\end{array}$ & $\begin{array}{c}0.107^{\star \star \star} \\
(0.031)\end{array}$ \\
\hline Skilled Workers Share & & & $\begin{array}{l}0.194^{\star \star \star} \\
(0.045)\end{array}$ & & & & & & & & \\
\hline Percentage of College-Educ. Workers & & & & $\begin{array}{l}0.133^{\star} \\
(0.077)\end{array}$ & & & & & & & \\
\hline Dummy for Managers with Post-Graduate Educ. & & & & & $\begin{array}{c}0.011 \\
(0.013)\end{array}$ & & & & & & \\
\hline Manager Years of Experience (log) & & & & & & $\begin{array}{l}0.014^{\star} \\
(0.008)\end{array}$ & & & & & \\
\hline Foreign-Owned Dummy & & & & & & & $\begin{array}{l}0.105^{\star \star} \\
(0.046)\end{array}$ & & & & \\
\hline Exporters Dummy & & & & & & & & $\begin{array}{c}0.033 \\
(0.022)\end{array}$ & & & \\
\hline Majority Exporters Dummy & & & & & & & & & $\begin{array}{c}0.086^{\star \star \star} \\
(0.025)\end{array}$ & & \\
\hline Years of Export Experience (log) & & & & & & & & & & $\begin{array}{c}0.049 \star \star \star \\
(0.009)\end{array}$ & \\
\hline Dummy for R\&D Staff & & & & & & & & & & & $\begin{array}{l}0.035^{\star \star} \\
(0.014)\end{array}$ \\
\hline Industry Fixed Effects & Yes & Yes & Yes & Yes & Yes & Yes & Yes & Yes & Yes & Yes & Yes \\
\hline Year Fixed Effects & Yes & Yes & Yes & Yes & Yes & Yes & Yes & Yes & Yes & Yes & Yes \\
\hline Location Fixed Effects & Yes & Yes & Yes & Yes & Yes & Yes & Yes & Yes & Yes & Yes & Yes \\
\hline $\begin{array}{l}\text { Number of Observations } \\
\text { R-squared }\end{array}$ & $\begin{array}{l}2486 \\
0.96 \\
\end{array}$ & $\begin{array}{l}2481 \\
0.96 \\
\end{array}$ & $\begin{array}{l}2464 \\
0.96 \\
\end{array}$ & $\begin{array}{l}2478 \\
0.96 \\
\end{array}$ & $\begin{array}{l}2478 \\
0.96 \\
\end{array}$ & $\begin{array}{l}2375 \\
0.96 \\
\end{array}$ & $\begin{array}{l}2478 \\
0.96 \\
\end{array}$ & $\begin{array}{l}2478 \\
0.96 \\
\end{array}$ & $\begin{array}{l}2478 \\
0.96 \\
\end{array}$ & $\begin{array}{l}2456 \\
0.96 \\
\end{array}$ & $\begin{array}{l}2478 \\
0.96 \\
\end{array}$ \\
\hline & (12) & (13) & (14) & (15) & (16) & (17) & (18) & $(19)$ & (20) & (21) & \\
\hline Very Large Dummy (150 to 500 Workers) & $\begin{array}{c}0.036^{\star \star \star} \\
(0.012)\end{array}$ & $\begin{array}{c}0.030^{\star \star \star} \\
(0.011)\end{array}$ & $\begin{array}{c}0.032^{\star \star \star} \\
(0.012)\end{array}$ & $\begin{array}{l}0.028^{\star \star} \\
(0.012)\end{array}$ & $\begin{array}{c}0.032^{\star \star \star} \\
(0.011)\end{array}$ & $\begin{array}{c}0.033^{\star \star \star} \\
(0.011)\end{array}$ & $\begin{array}{c}0.033^{\star \star \star} \\
(0.012)\end{array}$ & $\begin{array}{c}0.031^{\star \star \star} \\
(0.012)\end{array}$ & $\begin{array}{c}0.033^{\star \star \star} \\
(0.012)\end{array}$ & $\begin{array}{l}0.029^{\star \star} \\
(0.012)\end{array}$ & \\
\hline Relatively Large Dummy (50 to 150 Workers) & $\begin{array}{l}0.222^{\star \star \star} \\
(0.026)\end{array}$ & $\begin{array}{l}0.210^{\star \star \star} \\
(0.025)\end{array}$ & $\begin{array}{l}0.213^{\star \star \star} \\
(0.025)\end{array}$ & $\begin{array}{l}0.202^{\star \star \star} \\
(0.025)\end{array}$ & $\begin{array}{l}0.214^{\star \star \star} \\
(0.025)\end{array}$ & $\begin{array}{l}0.215^{\star \star \star} \\
(0.025)\end{array}$ & $\begin{array}{l}0.228^{\star \star \star} \\
(0.027)\end{array}$ & $\begin{array}{l}0.214^{\star \star \star} \\
(0.025)\end{array}$ & $\begin{array}{l}0.219^{\star \star \star} \\
(0.026)\end{array}$ & $\begin{array}{l}0.226^{\star \star \star} \\
(0.026)\end{array}$ & \\
\hline Medium Size Dummy (10 to 50 Workers) & $\begin{array}{l}0.198^{\star \star \star} \\
(0.050)\end{array}$ & $\begin{array}{l}0.186^{\star \star \star} \\
(0.048)\end{array}$ & $\begin{array}{l}0.189 \star \star \star \\
(0.048)\end{array}$ & $\begin{array}{c}0.168^{\star \star \star} \\
(0.048)\end{array}$ & $\begin{array}{l}0.187^{\star \star \star} \\
(0.048)\end{array}$ & $\begin{array}{c}0.193^{\star \star \star} \\
(0.048)\end{array}$ & $\begin{array}{l}0.173^{\star \star \star} \\
(0.062)\end{array}$ & $\begin{array}{l}0.185^{\star \star \star} \\
(0.051)\end{array}$ & $\begin{array}{l}0.201^{\star \star \star} \\
(0.050)\end{array}$ & $\begin{array}{c}0.188^{\star \star \star} \\
(0.048)\end{array}$ & \\
\hline Small Size Dummy (Less than 10 Workers) & $\begin{array}{c}0.155^{\star \star \star} \\
(0.047)\end{array}$ & $\begin{array}{c}0.128^{\star \star \star} \\
(0.046)\end{array}$ & $\begin{array}{c}0.147^{\star \star \star} \\
(0.048)\end{array}$ & $\begin{array}{l}0.114^{\star \star} \\
(0.046)\end{array}$ & $\begin{array}{c}0.136^{\star \star \star} \\
(0.047)\end{array}$ & $\begin{array}{c}0.157^{\star \star \star} \\
(0.048)\end{array}$ & $\begin{array}{c}0.217^{\star \star \star} \\
(0.062)\end{array}$ & $\begin{array}{c}0.146^{\star \star \star} \\
(0.048)\end{array}$ & $\begin{array}{c}0.151^{\star \star \star} \\
(0.047)\end{array}$ & $\begin{array}{c}0.148^{\star \star \star} \\
(0.047)\end{array}$ & \\
\hline Dummy for Firms Aged 5 to 10 Years Old & $\begin{array}{c}0.182^{\star \star \star} \\
(0.022)\end{array}$ & $\begin{array}{l}0.156^{\star \star \star} \\
(0.023)\end{array}$ & $\begin{array}{l}0.181^{\star \star \star} \\
(0.022)\end{array}$ & $\begin{array}{l}0.179^{\star \star \star} \\
(0.022)\end{array}$ & $\begin{array}{l}0.181^{\star * *} \\
(0.022)\end{array}$ & $\begin{array}{c}0.185^{\star \star \star} \\
(0.022)\end{array}$ & $\begin{array}{l}0.178^{\star \star \star} \\
(0.022)\end{array}$ & $\begin{array}{l}0.181^{\star \star \star} \\
(0.022)\end{array}$ & $\begin{array}{l}0.177^{\star \star \star} \\
(0.022)\end{array}$ & $\begin{array}{l}0.169^{\star \star \star} \\
(0.023)\end{array}$ & \\
\hline Dummy for Firms Aged 10 to 20 Years Old & $\begin{array}{c}0.228^{\star \star \star} \\
(0.023)\end{array}$ & $\begin{array}{l}0.198^{\star \star \star} \\
(0.025)\end{array}$ & $\begin{array}{l}0.229^{\star \star \star} \\
(0.023)\end{array}$ & $\begin{array}{c}0.231^{\star \star \star} \\
(0.023)\end{array}$ & $\begin{array}{l}0.231^{\star \star \star} \\
(0.023)\end{array}$ & $\begin{array}{c}0.230^{\star \star \star} \\
(0.023)\end{array}$ & $\begin{array}{c}0.228^{\star \star \star} \\
(0.023)\end{array}$ & $\begin{array}{l}0.230^{\star \star \star} \\
(0.023)\end{array}$ & $\begin{array}{l}0.230^{\star \star \star} \\
(0.023)\end{array}$ & $\begin{array}{c}0.231^{\star \star \star} \\
(0.024)\end{array}$ & \\
\hline Dummy for Firms Aged 20 to 40 Years Old & $\begin{array}{c}0.236^{\star \star \star} \\
(0.029)\end{array}$ & $\begin{array}{l}0.200^{\star \star \star} \\
(0.030)\end{array}$ & $\begin{array}{l}0.234^{\star \star \star} \\
(0.029)\end{array}$ & $\begin{array}{c}0.236^{\star \star \star} \\
(0.029)\end{array}$ & $\begin{array}{c}0.237^{\star \star \star} \\
(0.029)\end{array}$ & $\begin{array}{c}0.233^{\star \star \star} \\
(0.029)\end{array}$ & $\begin{array}{c}0.226 \star \star \star \\
(0.030)\end{array}$ & $\begin{array}{l}0.236^{\star \star \star} \\
(0.029)\end{array}$ & $\begin{array}{c}0.233^{\star \star \star} \\
(0.029)\end{array}$ & $\begin{array}{c}0.244^{\star \star \star} \\
(0.030)\end{array}$ & \\
\hline Dummy for Firms Aged More than 40 Years Old & $\begin{array}{c}0.107^{\star \star \star} \\
(0.032)\end{array}$ & $\begin{array}{l}0.077^{\star *} \\
(0.031)\end{array}$ & $\begin{array}{l}0.112^{\star \star \star} \\
(0.031)\end{array}$ & $\begin{array}{c}0.108^{\star \star \star} \\
(0.031)\end{array}$ & $\begin{array}{l}0.111^{\star \star \star} \\
(0.031)\end{array}$ & $\begin{array}{c}0.118^{\star \star \star} \\
(0.031)\end{array}$ & $\begin{array}{c}0.134^{\star \star \star} \\
(0.033)\end{array}$ & $\begin{array}{l}0.096^{\star \star \star} \\
(0.032)\end{array}$ & $\begin{array}{l}0.107^{\star \star \star} \\
(0.031)\end{array}$ & $\begin{array}{l}0.109^{\star \star \star} \\
(0.032)\end{array}$ & \\
\hline Quality Certification Dummy & $\begin{array}{l}0.034^{\star \star} \\
(0.016)\end{array}$ & & & & & & & & & & \\
\hline Perc. of Machinery Less than 5 Years Old & & $\begin{array}{l}-0.0006^{\star *} \\
(0.0002)\end{array}$ & & & & & & & & & \\
\hline Overdraft Dummy & & & $\begin{array}{c}0.005 \\
(0.014)\end{array}$ & & & & & & & & \\
\hline Loan Dummy & & & & $\begin{array}{c}-0.059 * \star \star \\
(0.014)\end{array}$ & & & & & & & \\
\hline Days to Clear Customs for Imports (log) & & & & & $\begin{array}{c}0.043 \\
(0.033)\end{array}$ & & & & & & \\
\hline Number of Power Interruptions (log) & & & & & & $\begin{array}{c}-0.090^{\star \star \star} \\
(0.025)\end{array}$ & & & & & \\
\hline Perc. Manag. Time Spent Dealing with Regulation & & & & & & & $\begin{array}{l}0.121^{\star \star} \\
(0.054)\end{array}$ & & & & \\
\hline Perc. of Firms Paying Bribes to Get Things Done & & & & & & & & $\begin{array}{c}0.023^{\star} \\
(0.013)\end{array}$ & & & \\
\hline Security Expenses as Perc. Sales & & & & & & & & & $\begin{array}{l}-2.365 \\
(1.549)\end{array}$ & & \\
\hline Protection Payments as Perc. Sales & & & & & & & & & & $\begin{array}{c}-33.866^{\star \star *} \\
(10.284)\end{array}$ & \\
\hline Industry Fixed Effects & Yes & Yes & Yes & Yes & Yes & Yes & Yes & Yes & Yes & Yes & \\
\hline Year Fixed Effects & Yes & Yes & Yes & Yes & Yes & Yes & Yes & Yes & Yes & Yes & \\
\hline Location Fixed Effects & Yes & Yes & Yes & Yes & Yes & Yes & Yes & Yes & Yes & Yes & \\
\hline Number of Observations & 2478 & 2478 & 2478 & 2478 & 2478 & 2478 & 2358 & 2455 & 2469 & 2371 & \\
\hline R-squared & 0.96 & 0.96 & 0.96 & 0.96 & 0.96 & 0.96 & 0.96 & 0.96 & 0.96 & 0.96 & \\
\hline
\end{tabular}

Notes: Robust standard errors in parenthesis. ${ }^{* * *}, * *$, and * indicate significance at $1 \%, 5 \%$, and $10 \%$ confidence levels, respectively. The omitted size category is extremely large firms (more than 500 workers) and the omitted age category is firms less than 5 years old. 